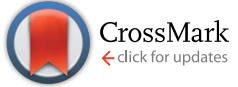

Cite this: RSC Adv., 2017, 7, 8786

\title{
Physico-chemical characteristics, biocompatibility, and MRI applicability of novel monodisperse PEG-modified magnetic $\mathrm{Fe}_{3} \mathrm{O}_{4} \& \mathrm{SiO}_{2}$ core-shell nanoparticles $\uparrow$
}

\author{
Uliana Kostiv, ${ }^{a}$ Vitalii Patsula, ${ }^{a}$ Miroslav Šlouf, ${ }^{a}$ Igor M. Pongrac, ${ }^{b}$ Siniša Škokić, ${ }^{b}$

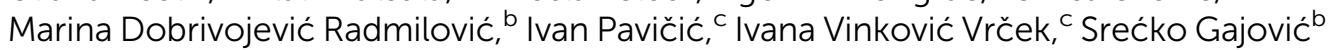 \\ and Daniel Horák ${ }^{\star a}$
}

\begin{abstract}
Monodisperse, superparamagnetic oleic acid-stabilized $\mathrm{Fe}_{3} \mathrm{O}_{4}$ nanoparticles of different sizes were prepared by thermal decomposition of $\mathrm{Fe}(\mathrm{III})$ oleate. The particles were subsequently coated by silica shells of different thicknesses (yielding $\mathrm{Fe}_{3} \mathrm{O}_{4} \& \mathrm{SiO}_{2}$ ) using a water-in-oil (w/o) reverse microemulsion technique and/or were decorated with amino groups by reaction with (3-aminopropyl)triethoxysilane. The resulting $\mathrm{Fe}_{3} \mathrm{O}_{4} \& \mathrm{SiO}_{2}-\mathrm{NH}_{2}$ nanoparticles were then modified with poly(ethylene glycol) (PEG) via reaction with its succinimidyl ester yielding $\mathrm{Fe}_{3} \mathrm{O}_{4} \& \mathrm{SiO}_{2}-\mathrm{PEG}$ particles. The in vitro biocompatibility and biosafety of the $\mathrm{Fe}_{3} \mathrm{O}_{4} 8 \mathrm{SiO}_{2}$ and $\mathrm{Fe}_{3} \mathrm{O}_{4} \& \mathrm{SiO}_{2}-\mathrm{PEG}$ particles were investigated in a murine neural stem cell model in terms of oxidative stress response and cell viability, proliferation, and uptake. Finally, the potential of both nanoparticle types for application in magnetic resonance imaging (MRI) visualization was evaluated.
\end{abstract}

Received 6th January 2017

Accepted 23rd January 2017

DOI: $10.1039 / \mathrm{c} 7 \mathrm{ra00224f}$

rsc.li/rsc-advances additional criteria. These involve low toxicity, biocompatibility, proper in vitro and in vivo interactions with living cells, and convenient dosage. ${ }^{13}$ Among the magnetic nanoparticles, a dominant role is played by iron oxides, mainly maghemite $(\gamma$ $\left.\mathrm{Fe}_{2} \mathrm{O}_{3}\right)$ and magnetite $\left(\mathrm{Fe}_{3} \mathrm{O}_{4}\right)$, which are known to be nontoxic (biocompatible) and have been approved by the Food and Drug Administration as a contrast agent for MRI. ${ }^{\mathbf{1 4 , 1 5}}$

Monodisperse magnetic nanoparticles with tunable properties are generally prepared by thermal decomposition of metal organic precursors; however, such particles are hydrophobic. Since bioapplications using nanomaterials require particle dispersibility in aqueous media, silica is often used as a coating material. ${ }^{16}$ Silica is biocompatible, optically transparent, chemically inert, thermally stable, and has a large surface area available for the loading of required drugs. ${ }^{17}$ In addition, silica can be easily modified with various reactive groups by the addition of appropriate silane derivatives during synthesis. Due to a large specific surface area and a negative charge, silicacoated magnetic nanoparticles have a tendency to adsorb proteins from blood plasma, which leads to undesirable particle aggregation. ${ }^{18}$ As a result, the particles are rapidly shuttled out of blood circulation and internalized by macrophages and endothelial cells of the reticuloendothelial system, in particular to the liver and spleen. ${ }^{19}$ To obtain not only a stable colloid without particle aggregation, but also prevent undesirable protein adsorption and prolong half-life time in the blood stream, the nanoparticle surface has to be further modified. The
${ }^{a}$ Institute of Macromolecular Chemistry, Academy of Sciences of the Czech Republic, Heyrovského nám. 2, 16206 Prague 6, Czech Republic.E-mail: horak@imc.cas.cz

${ }^{b}$ University of Zagreb, School of Medicine, Croatian Institute for Brain Research, Šalata 12, 10000 Zagreb, Croatia

'Institute for Medical Research and Occupational Health, Analytical Toxicology and Mineral Metabolism Unit, Ksaverska cesta 2, 10000 Zagreb, Croatia

$\dagger$ Electronic supplementary information (ESI) available. See DOI: 10.1039/c7ra00224f 
surface coating determines the interaction of the particles with the membranes of living cells. This controls the particle uptake by different cell types and influences biocompatibility, as well as the distribution of the nanoparticles in the tissues of living organisms. Recently, many materials, such as dopamine, ${ }^{\mathbf{2 0}}$ ascorbic acid, ${ }^{21}$ peptides, ${ }^{22}$ mono- ${ }^{23}$ and polysaccharides ${ }^{24}$ and poly(ethylene glycol) (PEG), ${ }^{25}$ have been proposed for particle coating by physical adsorption or chemical binding. PEG in particular is considered to be a very promising material, that protects the nanoparticles from the immune system, promotes a longer circulation time, and inhibits removal by the reticuloendothelial system. Moreover, PEG is inexpensive and FDAapproved for a wide range of bioapplications. ${ }^{25}$

The aim of this work is to design, prepare, and characterize monodisperse silica-coated magnetite nanoparticles $\left(\mathrm{Fe}_{3} \mathrm{O}_{4}\right.$ \&$\mathrm{SiO}_{2}$ ) with controlled shell thickness. Functionalization of the $\mathrm{Fe}_{3} \mathrm{O}_{4} \& \mathrm{SiO}_{2}$ surface with amino groups $\left(\mathrm{Fe}_{3} \mathrm{O}_{4} \& \mathrm{SiO}_{2}-\mathrm{NH}_{2}\right)$ and PEG $\left(\mathrm{Fe}_{3} \mathrm{O}_{4} \& \mathrm{SiO}_{2}\right.$-PEG) was another aim. The biocompatibility and biosafety of both $\mathrm{Fe}_{3} \mathrm{O}_{4} \& \mathrm{SiO}_{2}$ and $\mathrm{Fe}_{3} \mathrm{O}_{4} \& \mathrm{SiO}_{2}$-PEG particles were determined using a murine neural stem cell model, while their potential for biomedical use was evaluated by means of stem cell labeling and ex vivo MRI visualization of particles in the mouse brain.

\section{Experimental}

\subsection{Chemicals and materials}

Octadec-1-ene (OD), icosane (IS), tetramethyl orthosilicate (TMOS), (3-aminopropyl)triethoxysilane (APTES), Igepal CO-520 [polyoxyethylene(5) nonylphenylether], succinic anhydride, $N, N$ diisopropylethylamine, and Dulbecco's modified Eagle's medium (DMEM) were purchased from sigma-Aldrich (St. Louis, MO, USA). Oleic acid (OA), ammonium fluoride, acetone, dichloromethane (distilled), and ethanol were obtained from Lachema (Brno, Czech Republic). Methoxy poly(ethylene glycol) succinimidyl active ester (PEG-NHS; $M_{\mathrm{w}}=2000$ ) was purchased from Rapp Polymere (Tuebingen, Germany). Cellulose dialysis membranes (14 kDa) were obtained from Spectrum Europe (Breda, Netherlands). Fe(III) oleate was prepared according to an earlier report ${ }^{26}$ Ultrapure Q-water ultrafiltered on a Milli-Q Gradient A10 system (Millipore; Molsheim, France) was used in biological experiments.

Molecular Probes LIVE/DEAD ${ }^{\mathrm{TM}}$ viability/cytotoxicity and MTT (3-(4,5-dimethylthiazol-2-yl)-2,5-diphenyltetrazolium bromide) kits were from Invitrogen (Fisher Scientific; Hampton, NH, USA). DMEM/F-12, GlutaMAX, B27 factor, penicillin, streptomycin, epidermal growth factor (EGF), and fibroblast growth factor (FGF) were obtained from Life Technologies (Carlsbad, CA, USA). All other chemicals were purchased from Sigma-Aldrich.

Neural stem cell culture. Murine neural stem cells (mNSCs) were isolated from embryos of pregnant female mice (inbred strain $\mathrm{C} 57 \mathrm{Bl} / 6 \mathrm{NCrl}$ ) as previously described. ${ }^{27}$ All animal procedures were approved by the Internal Review Board of the Ethical Committee of the School of Medicine, University of Zagreb and were in accordance with the Ethical Codex of Croatian Society for Laboratory Animal Science and the EU
Directive 2010/63/EU on the protection of animals used for scientific purposes.

The telencephalic walls of embryos at gestation day 14.5 were microdissected and dissociated using StemPro Accutase (Life Technologies). Cells were maintained at $37{ }^{\circ} \mathrm{C}$ in a humidified $5 \% \quad \mathrm{CO}_{2}$ and $95 \% \mathrm{O}_{2}$ atmosphere. The expansion medium consisted of DMEM/F-12 with GlutaMAX, 1\% N-2 and 2\% B-27 supplements, $1 \%$ penicillin/streptomycin, $20 \mathrm{ng} \mathrm{mL} \mathrm{m}^{-1} \mathrm{EGF}$, and $10 \mathrm{ng} \mathrm{mL}{ }^{-1}$ FGF (all Life Technologies). The neurospheres were dissociated and mNSCs were plated in the single-cell state at densities of $2 \times 10^{6}, 8 \times 10^{5}, 4 \times 10^{4}$, and $1 \times 10^{4}$ cells per well on 6-, 12-, 24-, and 96-well plates, respectively. All plates were previously coated with aqueous poly(D-lysine) solution (50 $\mu \mathrm{g} \mathrm{mL}{ }^{-1}$; Sigma-Aldrich).

\subsection{Synthesis of $\mathrm{Fe}_{3} \mathrm{O}_{4}$ nanoparticles}

OA-stabilized $\mathrm{Fe}_{3} \mathrm{O}_{4}$ nanoparticles were obtained by thermal decomposition of $\mathrm{Fe}(\mathrm{III})$ oleate. ${ }^{26}$ To prepare 6 and $10 \mathrm{~nm} \mathrm{Fe}_{3} \mathrm{O}_{4}$ nanoparticles, Fe(II) oleate $(7.2 \mathrm{~g} ; 8 \mathrm{mmol})$ was dissolved in a mixture of solvent ( $38 \mathrm{~mL}$ of $\mathrm{OD}$ ) and stabilizer (4.55 and 3.6 $\mathrm{mL}$ of OA, respectively). $20 \mathrm{~nm} \mathrm{Fe}_{3} \mathrm{O}_{4}$ nanoparticles were obtained analogously in IS $(38 \mathrm{~mL})$ with $\mathrm{OA}(3.6 \mathrm{~mL})$ as a stabilizer. The reaction mixture was degassed at $95{ }^{\circ} \mathrm{C}$ for $20 \mathrm{~min}$ in vacuum $(\sim 1.3 \mathrm{kPa})$ and heated at $320^{\circ} \mathrm{C}$ for $30 \mathrm{~min}$ (in OD) or at $343{ }^{\circ} \mathrm{C}$ for $60 \mathrm{~min}$ (in IS). After cooling to room temperature (RT), ethanol (100 $\mathrm{mL})$ was added to the reaction mixture, and the resulting particles were separated by a magnet. The nanoparticles were washed ten times with hot ethanol $\left(60-70{ }^{\circ} \mathrm{C} ; 50\right.$ $\mathrm{mL}$ each) to remove residual solvents and OA. Finally, the $\mathrm{Fe}_{3} \mathrm{O}_{4}$ nanoparticles were dispersed in hexane.

\subsection{Synthesis of $\mathrm{Fe}_{3} \mathrm{O}_{4} \& \mathrm{SiO}_{2}$ and $\mathrm{Fe}_{3} \mathrm{O}_{4} \& \mathrm{SiO}_{2}-\mathrm{NH}_{2}$ nanoparticles}

$\mathrm{Fe}_{3} \mathrm{O}_{4} \& \mathrm{SiO}_{2}$ and $\mathrm{Fe}_{3} \mathrm{O}_{4} \& \mathrm{SiO}_{2}-\mathrm{NH}_{2}$ particles were obtained by a water-in-oil (w/o) reverse microemulsion technique. ${ }^{28,29}$ To a dispersion of $\mathrm{Fe}_{3} \mathrm{O}_{4}$ nanoparticles $(30 \mathrm{mg})$ in hexane $(10 \mathrm{~mL})$, Igepal CO-520 $(0.5 \mathrm{~mL})$ and $25 \% \mathrm{NH}_{4} \mathrm{OH}(0.08 \mathrm{~mL})$ were added, and the mixture was sonicated (Sonopuls sonicator; Bandelin; Berlin, Germany) at RT for $30 \mathrm{~min}$. After addition of TMOS (0.04 $\mathrm{mL})$, the reaction mixture was stirred (600 rpm) at RT for $48 \mathrm{~h}$. To produce $\mathrm{Fe}_{3} \mathrm{O}_{4} \& \mathrm{SiO}_{2}-\mathrm{NH}_{2}$ nanoparticles, APTES $(0.02 \mathrm{~mL})$ was added, and the reaction was continued at RT for an additional 24 h. $\mathrm{Fe}_{3} \mathrm{O}_{4} \& \mathrm{SiO}_{2}$ and $\mathrm{Fe}_{3} \mathrm{O}_{4} \& \mathrm{SiO}_{2}-\mathrm{NH}_{2}$ nanoparticles were precipitated in acetone $(10 \mathrm{~mL})$, separated by centrifugation (4000 rpm), and washed with ethanol and water five times each to remove residual surfactant. Finally, the nanoparticles were dialyzed against water at RT for $48 \mathrm{~h}$ using Spectra/Por® cellulose membrane (14 kDa; Spectrum; Rancho Dominguez, CA, USA).

\subsection{PEGylation of $\mathrm{Fe}_{3} \mathrm{O}_{4} \& \mathrm{SiO}_{2}-\mathrm{NH}_{2}$ nanoparticles}

To PEGylate the $\mathrm{Fe}_{3} \mathrm{O}_{4} \& \mathrm{SiO}_{2}-\mathrm{NH}_{2}$ particles $(30 \mathrm{mg}$ ), they were dispersed in dichloromethane $(10 \mathrm{~mL})$, PEG-NHS $(40 \mathrm{mg})$ was added, and the mixture was stirred (200 rpm) at RT for $12 \mathrm{~h}$. Residual amino groups on the particles were reacted with succinic anhydride $(10 \mathrm{mg})$ and $N, N$-diisopropylethylamine $(25 \mu \mathrm{L})$ 
at RT for $1 \mathrm{~h}$ with stirring $(200 \mathrm{rpm})$. The resulting $\mathrm{Fe}_{3} \mathrm{O}_{4} \& \mathrm{SiO}_{2}-$ PEG particles were precipitated by acetone $(5 \mathrm{~mL})$, dispersed in ethanol, purged with Ar for 10 min to remove dichloromethane, separated by centrifugation (4000 rpm), dispersed in water, and finally dialyzed against water at RT for $24 \mathrm{~h}$ to remove unreacted PEG.

\subsection{Physico-chemical characterization of the nanoparticles}

Electron microscopy. The morphology (shape, diameter, and size distribution), crystal structure, and composition of the magnetic particles were investigated using a Tecnai G2 Spirit Twin 12 transmission electron microscope (TEM; FEI; Brno, Czech Republic) equipped with an energy dispersive spectrometer (EDX; Mahwah, NJ, USA). The weight-averaged diameter $\left(D_{\mathrm{w}}\right)$, number-averaged diameter $\left(D_{\mathrm{n}}\right)$, and uniformity (polydispersity index PDI $=D_{\mathrm{w}} / D_{\mathrm{n}}$ ) were calculated from at least 500 individual particles using Atlas software (Tescan; Brno, Czech Republic). $D_{\mathrm{n}}$ and $D_{\mathrm{w}}$ were calculated as follows:

$$
\begin{gathered}
D_{\mathrm{n}}=\sum n_{\mathrm{i}} D_{\mathrm{i}} / \sum n_{\mathrm{i}} \\
D_{\mathrm{w}}=\sum n_{\mathrm{i}} D_{\mathrm{i}}{ }^{4} / \sum n_{\mathrm{i}} D_{\mathrm{i}}{ }^{3},
\end{gathered}
$$

where $n_{\mathrm{i}}$ and $D_{\mathrm{i}}$ are the number and diameter of the nanoparticle, respectively. The crystal structure of the nanoparticles was verified by selected area electron diffraction (SAED). The SAED patterns were processed with ProcessDiffraction software $^{30}$ and compared with the theoretical diffraction patterns of magnetite $\left(\mathrm{Fe}_{3} \mathrm{O}_{4}\right)$, which were calculated with PowderCell software. ${ }^{31}$ The $\mathrm{Fe}_{3} \mathrm{O}_{4}$ crystal structure was obtained from the Crystallography Open Database. ${ }^{32}$

Dynamic light scattering. The hydrodynamic particle diameter $D_{\mathrm{h}}$, polydispersity PD characterizing size distribution, and $\zeta$-potential of nanoparticle dispersions in water $\left(0.1 \mathrm{mg} \mathrm{mL}^{-1}\right.$; pH 6.4) were determined by dynamic light scattering (DLS) on a ZEN 3600 Zetasizer Nano Instrument (Malvern Instruments; Malvern, UK) at RT.

ATR FTIR spectroscopy. IR spectra of the dried particles were recorded on a Nexus Nicolet 870 FT-IR spectrometer (Madison, WI, USA) equipped with a liquid nitrogen-cooled mercury cadmium telluride detector using a Golden Gate single attenuated total reflection (ATR) crystal (Specac Ltd.; Slough, UK) at a resolution of $4 \mathrm{~cm}^{-1}$. Water vapor (atmospheric spectrum) was subtracted from the spectra and linear baseline and ATR correction were applied.

\subsection{Labeling efficiency of $\mathrm{Fe}_{3} \mathrm{O}_{4} \& \mathrm{SiO}_{2}$ and $\mathrm{Fe}_{3} \mathrm{O}_{4} \& \mathrm{SiO}_{2}$-PEG nanoparticles}

Flow cytometry experiments. Flow cytometry experiments using an Attune ${ }^{\circledR}$ acoustic focusing flow cytometer (Applied Biosystems; Foster City, CA, USA) with a $488 \mathrm{~nm}$ laser evaluated the labeling efficiency of mNSCs by $\mathrm{Fe}_{3} \mathrm{O}_{4} \& \mathrm{SiO}_{2}$ and $\mathrm{Fe}_{3} \mathrm{O}_{4}$ \&$\mathrm{SiO}_{2}$-PEG particles. The cytometer was set up to measure linear forward and logarithmic side-scattered light of the laser beam (SSC). Internalization of the nanoparticles in mNSCs was evaluated using a Molecular Probes LIVE/DEAD ${ }^{\mathrm{TM}}$ viability/ cytotoxicity kit. Cells were seeded in 6-well plates and incubated with increasing particle concentrations $(2,20$, and $200 \mathrm{mg}$ $\mathrm{L}^{-1}$ ) for $24 \mathrm{~h}$. The highest nanoparticle dose was run first to set the range for the maximum SSC signal. Non-treated cells were used as a negative control. Dissociated cells were incubated with $0.1 \mu \mathrm{M}$ calcein acetoxymethyl ester (CAM) and $3 \mu \mathrm{M}$ ethidium homodimer-1 (EthD), both supplied in the kit, at RT for $15 \mathrm{~min}$ in the dark. Each experiment was repeated three times. CAM and EthD were measured using log amplifiers. The percentage of particle-labeled cells was determined by measuring the increase in the SSC signal. The SSC intensity was proportional to the intracellular density and granularity. ${ }^{33}$ The percentage of positive cells (compared to the control) was determined with FCS Express 5 flow cytometry software using the Overton cumulative histogram subtraction method. ${ }^{34}$

Prussian blue staining. After treatment with different concentrations of $\mathrm{Fe}_{3} \mathrm{O}_{4} \& \mathrm{SiO}_{2}$ and $\mathrm{Fe}_{3} \mathrm{O}_{4} \& \mathrm{SiO}_{2}$-PEG particles for $24 \mathrm{~h}$, the cells were washed three times with phosphate-buffered saline (PBS) to remove the particles, fixed with $4 \%$ paraformaldehyde for $20 \mathrm{~min}$, and stained with a mixture of $10 \%$ $\mathrm{K}_{4} \mathrm{Fe}(\mathrm{CN})_{6}$ and $20 \% \mathrm{HCl}\left(1: 1 \mathrm{~mol} \mathrm{~mol}^{-1}\right)$ for $20 \mathrm{~min}$. Cells were counterstained with $0.1 \%$ nuclear fast red for $1 \mathrm{~min}$, mounted with HistoMount (Invitrogen), and covered by coverslips. After drying, the cells were viewed using an ECLIPSE E200 light microscope (Nikon Instruments; Tokyo, Japan) under bright field.

Determination of particle uptake by inductively coupled plasma mass spectrometry (ICP-MS). The cells were seeded in 6well tissue culture plates, exposed to $\mathrm{Fe}_{3} \mathrm{O}_{4} \& \mathrm{SiO}_{2}$ or $\mathrm{Fe}_{3} \mathrm{O}_{4} \& \mathrm{SiO}_{2}$ PEG nanoparticles for $24 \mathrm{~h}$, washed several times with PBS, and suspended in $10 \mathrm{mM}$ phosphate buffer ( $\mathrm{pH} 7.5)$. The harvested cells were transferred in closed vessels and digested with an UltraCLAVE IV Milestone digestion device (MikrowellenLaborsysteme; Leutkirch, Germany) using the US EPA 3052 method. The particle uptake by the mNSCs was quantified by measuring the total Fe contents in the digested cells by an Agilent Technologies 7500cx ICP-MS (Waldbronn, Germany).

TEM of particle-labelled mNSCs. After labeling, the cells were detached from the surface by a $10 \mathrm{~min}$ treatment with StemPro Accutase reagent, washed once with DMEM/F-12 medium, separated by centrifugation, fixed overnight with $2 \%$ glutaraldehyde in $0.1 \mathrm{M}$ phosphate buffer, post-fixed in $1 \%$ osmium tetroxide, and contrasted in $2 \%$ uranyl acetate. The cells were dehydrated in acetone and embedded in Durcupan resin. Ultrathin sections were then cut on an RMC Power Tome XL ultramicrotome (Boeckeler Instruments; Tucson, AZ, USA) and were contrasted with uranyl acetate and lead citrate and visualized using a 902A TEM microscope (Zeiss; Oberkochen, Germany).

\subsection{Biocompatibility and biosafety of $\mathrm{Fe}_{3} \mathrm{O}_{4} \& \mathrm{SiO}_{2}$ and $\mathrm{Fe}_{3} \mathrm{O}_{4} \& \mathrm{SiO}_{2}$-PEG nanoparticles}

Cell viability assay. Cell viability was determined by measuring the cellular metabolic activity using the MTT assay based on the reduction of the yellow tetrazolium salt to purple formazan crystals. mNSCs were plated on a 96-well plate in 
DMEM/F-12 medium with GlutaMAX for $24 \mathrm{~h} . \mathrm{Fe}_{3} \mathrm{O}_{4} \& \mathrm{SiO}_{2}$ and $\mathrm{Fe}_{3} \mathrm{O}_{4} \& \mathrm{SiO}_{2}$-PEG nanoparticles were added to quintuplicate wells at concentrations ranging over $0-200 \mathrm{mg} \mathrm{L}^{-1}$ and incubated for another $24 \mathrm{~h}$. Non-treated cells were used as negative controls, while mNSCs treated with dimethyl sulfoxide (DMSO) were used as positive controls. After the treatment, the medium from each well was removed by aspiration, the cells were carefully washed three times with $200 \mu \mathrm{L}$ PBS per well to remove all particles that may interfere with the MTT assay, ${ }^{35}$ MTT solution $\left(50 \mu \mathrm{L} ; 1000 \mathrm{mg} \mathrm{L}^{-1}\right)$ was added to each well, and the cells were incubated at $37^{\circ} \mathrm{C}$ for $4 \mathrm{~h}$. The MTT solution from each well was removed by aspiration, which was followed by the addition of DMSO $(50 \mu \mathrm{L})$ to dissolve formazan crystals. The optical density was measured in each well using a Victor $^{\mathrm{TM}}$ multilabel plate reader (Perkin Elmer; Waltham, MA, USA) at $595 \mathrm{~nm}$. In addition, control plates with the same particle concentrations were prepared, and the background absorbance of particles was subtracted on the plate reader to avoid false positive results that may lead to an underestimation of particle toxicity. ${ }^{35}$

mNSCs survival/mortality. Flow cytometry evaluated the effect of the particles on mNSC survival using an Attune ${ }^{\circledR}$ acoustic focusing flow cytometer. mNSCs were seeded in 6-well plates and incubated with increasing concentrations of $\mathrm{Fe}_{3}$ $\mathrm{O}_{4} \& \mathrm{SiO}_{2}$ and $\mathrm{Fe}_{3} \mathrm{O}_{4} \& \mathrm{SiO}_{2}$-PEG particles $\left(0-200 \mathrm{mg} \mathrm{L}{ }^{-1}\right)$. Nontreated cells were used as negative controls. Cell survival was evaluated using a CAM/EthH LIVE/DEAD ${ }^{\text {TM }}$ viability/cytotoxicity kit. The percentage of positive cells (compared to the negative control) was determined with FCS Express 5 flow cytometry software using the Overton cumulative histogram subtraction method. ${ }^{34}$ Cell survival was expressed as a percentage of "live" cells $\left(\mathrm{CAM}^{+} \mathrm{EthH}^{-}\right)$, while cell mortality was expressed as a percentage of "dead" and "dying" cells $\left(\mathrm{CAM}^{-} \mathrm{EthH}^{+}\right.$and $\mathrm{CAM}^{+} \mathrm{EthH}^{+}$, respectively).

Reactive oxygen species (ROS) production. Reactive oxygen species (ROS) production in mNSCs treated with the particles was determined using $2^{\prime}, 7^{\prime}$-dichlorodihydrofluorescein diacetate (DCFH-DA), which penetrates cell membranes freely and is hydrolyzed by cellular esterases to form $2^{\prime}, 7^{\prime}$-dichlorodihydrofluorescein, which is oxidized to the fluorescent $2^{\prime}, 7^{\prime}$-dichlorofluorescein (DCF) in the presence of hydroxyl radicals. ${ }^{36}$ Cells were exposed to increasing concentrations of $\mathrm{Fe}_{3} \mathrm{O}_{4} \& \mathrm{SiO}_{2}$ or $\mathrm{Fe}_{3} \mathrm{O}_{4} \& \mathrm{SiO}_{2}$-PEG nanoparticles $\left(20,100\right.$, and $\left.100 \mathrm{mg} \mathrm{L}^{-1}\right)$ at $37^{\circ} \mathrm{C}$ for $4 \mathrm{~h}$. Non-treated cells were used as negative controls, while cells treated with $100 \mu \mathrm{M} \mathrm{H}_{2} \mathrm{O}_{2}$ were positive controls. After treatment, the cells were washed three times with PBS (to avoid interference with the particles), which was followed by staining with $20 \mu \mathrm{M}$ DCFH-DA at $37{ }^{\circ} \mathrm{C}$ for $30 \mathrm{~min}$. Cells were then washed with PBS twice and analyzed using a Victor ${ }^{\mathrm{TM}}$ multilabel plate reader at excitation and emission wavelengths of 485 and $535 \mathrm{~nm}$, respectively. The data were expressed as percentage of fluorescence compared to the relevant negative controls.

Quantification of intracellular glutathione (GSH). The effect of treatment with increasing concentrations of $\mathrm{Fe}_{3} \mathrm{O}_{4} \& \mathrm{SiO}_{2}$ or $\mathrm{Fe}_{3} \mathrm{O}_{4} \& \mathrm{SiO}_{2}$-PEG nanoparticles on the cellular level of intracellular GSH was estimated using a monochlorobimane $(\mathrm{MBCl})$ probe, which reacts specifically with GSH to form a fluorescent adduct. ${ }^{37}$ After treatment with the particles at $37{ }^{\circ} \mathrm{C}$ for $4 \mathrm{~h}$, the mNSCs were washed three times with PBS, which was followed by incubation with $50 \mu \mathrm{M} \mathrm{MBCl}$ at $37{ }^{\circ} \mathrm{C}$ for $20 \mathrm{~min}$. The cells were then washed twice with PBS and analyzed using a Victor ${ }^{\mathrm{TM}}$ multilabel plate reader at excitation and emission wavelengths of 355 and $460 \mathrm{~nm}$, respectively. Negative (non-treated) and positive cell controls (treated with $100 \mu \mathrm{M} \mathrm{H}_{2} \mathrm{O}_{2}$ ) were included. All data were expressed as percentage of fluorescence compared to relevant negative controls.

Measurement of mitochondrial membrane potential (MMP). Measurement of mitochondrial membrane potential (MMP) was based on determination of the 3,3'-dihexyloxacarbocyanine iodide $\left(\mathrm{DiOC}_{6}\right)$ concentration $(\mathrm{nM})$, which is a lipophilic fluorescent dye that rapidly enters the mitochondria and is then released during mitochondrial membrane depolarization. ${ }^{38}$ Cells were incubated with the particles at $37^{\circ} \mathrm{C}$ for $4 \mathrm{~h}$, washed with PBS three times to avoid interferences with $\mathrm{DiOC}_{6}$, and stained with $20 \mathrm{nM} \mathrm{DiOC}_{6}$ at $37^{\circ} \mathrm{C}$ for $30 \mathrm{~min}$. The stained cells were washed with PBS and analyzed on a Victor ${ }^{\mathrm{TM}}$ multiplate reader at excitation and emission wavelengths of 485 and $510 \mathrm{~nm}$, respectively. Negative (non-treated) and positive cell controls (treated with $500 \mu \mathrm{M} \mathrm{H}_{2} \mathrm{O}_{2}$ ) were included in each experiment. The data were expressed as percentage of fluorescence compared to relevant negative controls.

\subsection{Ex vivo MRI visibility validation of $\mathrm{Fe}_{3} \mathrm{O}_{4} \& \mathrm{SiO}_{2}$ and $\mathrm{Fe}_{3} \mathrm{O}_{4} \& \mathrm{SiO}_{2}$-PEG nanoparticles in mouse brain}

Magnetic resonance imaging (MRI) was performed on a $7 \mathrm{~T}$ BioSpec 70/20 USR system (Bruker Biospin; Ettlingen, Germany) with Paravision 6.0.1. software in a configuration using an 86 mm MT0381 transmit volume coil and a 2-element MT0042 mouse brain surface receiver coil. The samples were placed in a suitable plastic tube, which was taped to the receiver coil to lay the region of interest in the center of the field of view (FOV).

MRI relaxometry on phantoms. The phantoms consisted of $\mathrm{Fe}_{3} \mathrm{O}_{4} \& \mathrm{SiO}_{2}$ and $\mathrm{Fe}_{3} \mathrm{O}_{4} \& \mathrm{SiO}_{2}$-PEG nanoparticles suspended in a host medium ( $20 \mathrm{vol} \%$ glycerol) and sealed in a $0.2 \mathrm{~mL}$ flat-top tube. Maps of $T_{1}, T_{2}$, and $T_{2}^{*}$ relaxation times were measured for each particle type at three different concentrations $(10,40$, and $100 \mathrm{mg} \mathrm{L}^{-1}$ ) and host medium. $T_{1}, T_{2}$, and $T_{2}^{*}$ were compared to the results measured on native host media in the absence of the particles. The geometric parameters for all mapping sequences were identical. Two $1 \mathrm{~mm}$ thick slices in the FOV center, perpendicular to the phantom tube, were acquired with inplane isotropic resolution of $133 \mu \mathrm{m}$ and slice spacing of 0.3 $\mathrm{mm}$. Prior to the main scans, a localizer scan was run, followed by additional local shimming using the MAPSHIM algorithm. This was done to ensure field homogeneity comparable to typical in vivo levels, which increases the relevance of measured $T_{2}^{*}$ values. The sequence-specific parameters used are listed in Table S1 of ESI. $\dagger$ After acquisition, relaxation maps were calculated using Paravision's built-in post-processing tools (FitInISA macro). Circular regions of interest covering roughly one half of the tube cross-section were placed centrally over each map to avoid artifacts due to abrupt susceptibility changes between the phantom and the plastic tube. One or more 
shimming iterations were done, until the calculated half-power bandwidth (HPBW) of the proton frequency line was comparable to typical values obtained when applying the MAPSHIM algorithm in vivo on a mouse brain.

Ex vivo MRI visibility validation of nanoparticles in mouse brain. $\mathrm{Fe}_{3} \mathrm{O}_{4} \& \mathrm{SiO}_{2}$ and $\mathrm{Fe}_{3} \mathrm{O}_{4} \& \mathrm{SiO}_{2}$-PEG nanoparticles were stereotaxically injected into four isolated adult mouse brains. Mice (three months-old, weighing 25-30 g) were transcardially perfused and the brains were isolated and kept in $4 \%(\mathrm{v} / \mathrm{v})$ paraformaldehyde for $24 \mathrm{~h}$ prior to the injection. The nanoparticle dispersion was injected in the left side of the brain, while the control solution containing only host medium (20 vol\% glycerol) was injected in the right side of the brain. The procedure was performed using a 900LS KOPF stereotaxic apparatus (Tujunga, CA, USA) and a $5 \mu \mathrm{L}$ Hamilton syringe needle (Fig. S1a in ESI $\dagger$ ). The injections were applied in the front part of the cerebrum at approximate stereotaxic coordinates of $\mathrm{ML} \pm 2.0, \mathrm{DV}-2.0$ and $\mathrm{AP}-0.2$ according to the stereotaxic atlas. ${ }^{39}$ Before injecting, the needle was slightly retracted to create a small pocket for the injected liquid and to prevent spillage. The brain was then placed in a $1.8 \mathrm{~mL}$ freezer tube filled with Fomblin (Solvay; Brussels, Belgium) and held in place with a custom cut piece of thin plastic inserted below (Fig. S1b in ESI $\dagger$ ). The tube was taped to the receiver coil with the brain top facing upwards for optimal signal-to-noise performance.

Ex vivo MRI visualization. For ex vivo validation of MRI visibility of the particles in mouse brain, two high-resolution scans based on standard imaging sequences were performed: spin echo-based $T_{2^{-}}$and gradient echo-based $T_{2}^{*}$-weighted sequences using sequence-specific parameters (Table S2 in ESI†). Twelve axial slices covering the whole length of the cerebrum were set. The slice thickness was reduced to $0.5 \mathrm{~mm}$, and an in-plane resolution of $80 \times 80 \mu \mathrm{m}$ was chosen for the scans. The reduced voxel size compared to the phantom measurement $(>5 \times$ smaller volume) and the lower inherent contrast of fixed tissue compared to the live organ was compensated by an increased number of averaging repetitions. No additional post-processing was done on the acquired images.

\section{Results and discussion}

\subsection{Magnetite nanoparticles}

Superparamagnetic $\mathrm{Fe}_{3} \mathrm{O}_{4}$ particles were obtained by OAstabilized thermal decomposition of $\mathrm{Fe}(\mathrm{III})$ oleate. A large advantage of this technique is that it provides monodisperse particles, the size of which can be controlled in the $6-20 \mathrm{~nm}$ range by changing the reaction temperature and the concentration of the $\mathrm{OA}$ stabilizer. The tunable particle size and uniformity, as well as the reproducibility of the synthesis, are of critical importance for prospective bioapplications. The reaction temperature was controlled by selecting high-boiling solvents, such as OD and IS. As OD has a lower boiling temperature than IS, the reaction in OD produced the smaller particles No. I and II (6 and $10 \mathrm{~nm}$; Fig. 1a and d, respectively) compared to the particles no. III prepared in IS ( $20 \mathrm{~nm}$; Fig. 1g),
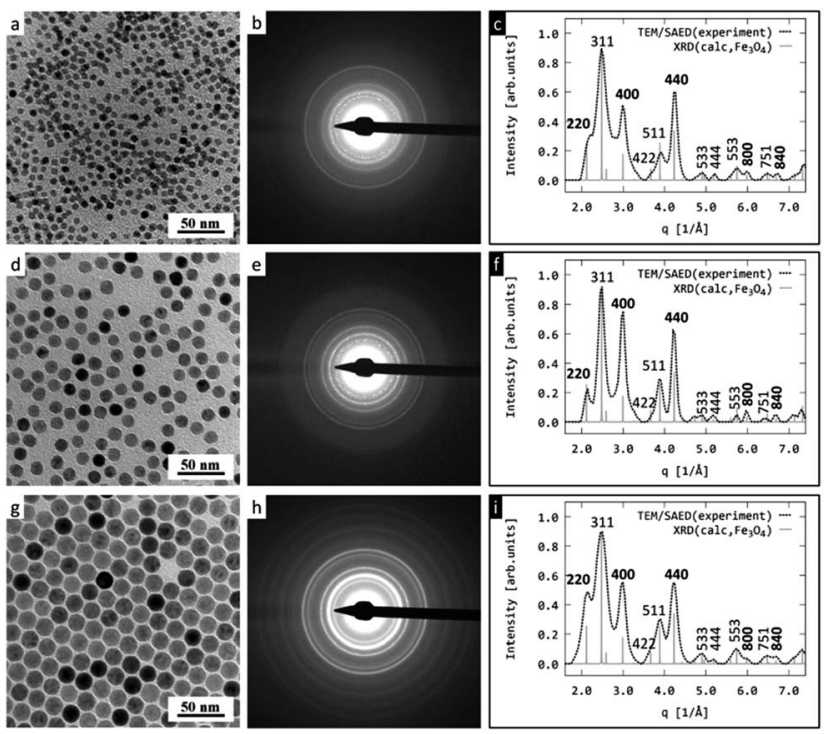

Fig. 1 Crystal structure of the $\mathrm{Fe}_{3} \mathrm{O}_{4}$ nanoparticles. TEM/BF micrographs of (a) 6, (d) 10, and (g) $20 \mathrm{~nm} \mathrm{Fe}_{3} \mathrm{O}_{4}$ nanoparticles, (b, e and h) the corresponding experimental TEM/SAED diffraction patterns, and ( $c, f$ and i) comparison of the radially averaged SAED diffraction patterns with theoretically calculated XRD diffraction patterns of $\mathrm{Fe}_{3} \mathrm{O}_{4}$. Each row corresponds to one TEM analysis. The diffraction indices ( $h k l)$ given in the right column in bold correspond to diffractions enhanced due to the preferred orientation of the $\mathrm{Fe}_{3} \mathrm{O}_{4}$ nanocrystals (zone axis [001]).

which was demonstrated by TEM. While the $10 \mathrm{~nm} \mathrm{Fe}_{3} \mathrm{O}_{4}$ particles were formed at a lower OA concentration $(0.3 \mathrm{mmol}$ $\mathrm{mL}^{-1}$ ), the $6 \mathrm{~nm}$ ones were synthesized in the presence of higher OA concentration $\left(0.38 \mathrm{mmol} \mathrm{mL}^{-1}\right)$. This is because an increased amount of stabilizer (OA) always produces smaller entities because it stabilizes more particles. ${ }^{26,40}$

The morphology, coating, elemental composition, and crystal structure of the particles were verified by TEM analysis including bright field imaging (TEM/BF), energy-dispersive $\mathrm{X}$ rays analysis (TEM/EDX), and selected area electron diffraction (TEM/SAED). The TEM analysis was supplemented by FTIR measurements. The TEM/BF micrographs (Fig. 1a, d and g) show the nanoparticle sizes as a function of experimental conditions; the $\mathrm{SiO}_{2}$-coating on the nanoparticle surface is seen in Fig. 2.

TEM/SAED diffraction patterns confirmed that the nanoparticles were the magnetic form of iron oxide, i.e., magnetite $\left(\mathrm{Fe}_{3} \mathrm{O}_{4}\right)$. Fig. 1a, $\mathrm{d}$ and $\mathrm{g}$ shows the TEM/BF micrographs of nanoparticles with various sizes; the medium column displays the corresponding two-dimensional experimental TEM/SAED diffraction patterns (Fig. 1b, e and h), and the right column compares the one-dimensional, radially averaged SAED diffractograms with theoretically calculated XRD diffractograms of magnetite (Fig. 1c, f and i). The SAED diffraction positions were in excellent agreement with the calculated XRD positions, while the SAED diffraction intensities of several reflections (440 and 400) were slightly different from the calculated XRD intensities (Fig. 1c, f and i). This difference could be attributed to the preferred orientation of the faceted $\mathrm{Fe}_{3} \mathrm{O}_{4}$ nanocrystals lying on 


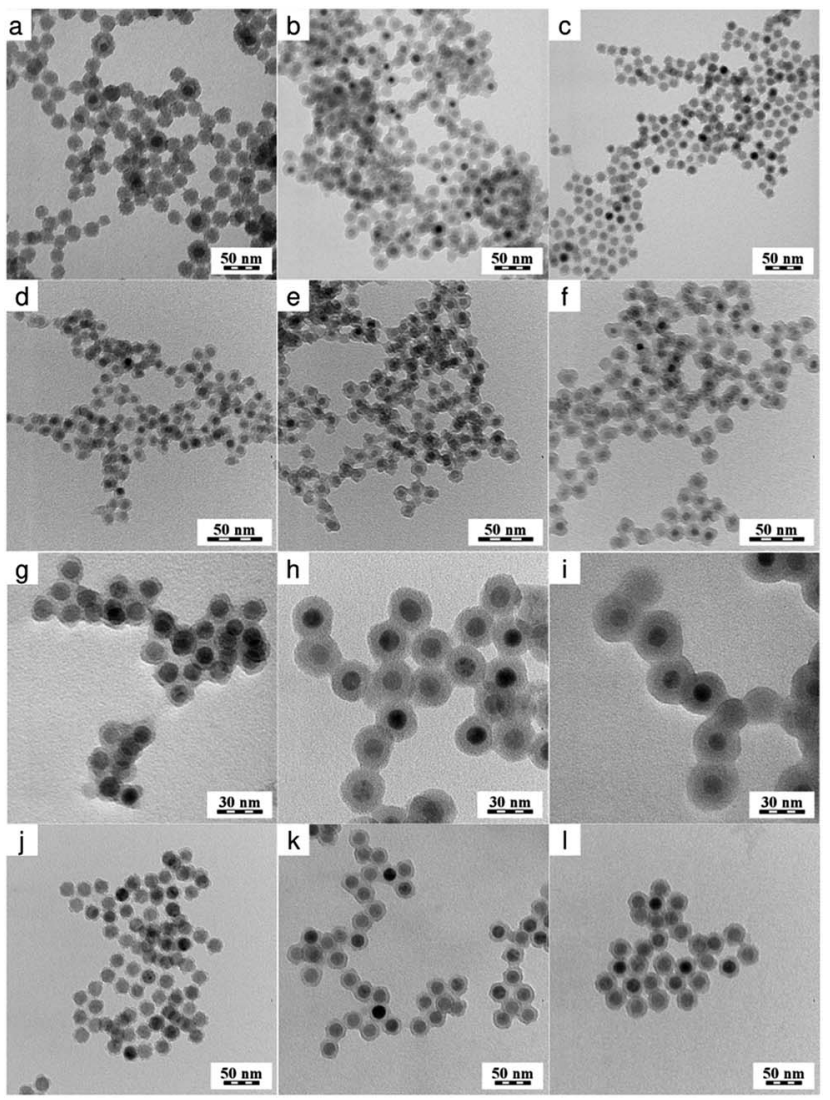

Fig. 2 TEM micrographs of $\mathrm{Fe}_{3} \mathrm{O}_{4} \& \mathrm{SiO}_{2}$ nanoparticles prepared from

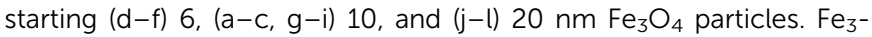
$\mathrm{O}_{4} \& \mathrm{SiO}_{2}$ nanoparticles prepared at (a) 40/10, (b) 40/30, (c) 40/80, (d) 40/30, (e) 80/30, (f) 120/30, (g) 20/30, (h) 40/30, (i) 60/30, (j) 50/30, (k) 120/30, and (l) $150 / 30 \mu \mathrm{L} \mathrm{mg}{ }^{-1} \mathrm{TMOS} / \mathrm{Fe}_{3} \mathrm{O}_{4}$ ratios.

the electron-transparent carbon film. Diffractions that were stronger in SAED than in XRD were of the (hk0) type, i.e., their last diffraction index was zero. This indicated that the orientation of a significant quantity of the nanocrystals could be characterized by zone axis [001], and the strong diffractions of the SAED pattern came from the zonal planes obeying the Weiss Zone Law (WZL). The general formula of WLS reads: $h u+k v+l w$ $=0$, where $(h, k, l)$ are the diffraction indices and $(u, v, w)$ are the indices of the zone axis. In our specific case with zone axis [uvw] $=[001]$, the WZL was reduced to the simple form $(l=0)$, and as a result the strongest SAED diffractions were $(h k 0)$ as discussed above and shown in Fig. 1. For the 6 and $10 \mathrm{~nm}$ nanocrystals (Fig. 1a and d), the diffraction (220) was not very strong despite obeying the WZL. This was due to the small nanocrystals (Fig. 1b and e) exhibiting less intensive diffractions than the large ones (Fig. 1h). As a result, the (220) diffraction was partially lost in the intensity of the neighboring primary beam. More details about zone axis, WZL and SAED interpretation can be found elsewhere. ${ }^{41}$ Here, we simply conclude that the agreement between the experimental SAED and calculated XRD patterns demonstrated that all prepared iron oxide nanoparticles had the $\mathrm{Fe}_{3} \mathrm{O}_{4}$ crystal structure.

The diameter of the magnetic nanoparticles in hexane was additionally measured by DLS. The hydrodynamic diameter $\left(D_{\mathrm{h}}\right)$ and polydispersity (PD) of No. I, II, and III nanoparticles reached 10,31 , and $41 \mathrm{~nm}$ and $0.12,0.15$, and 0.19 , respectively, confirming a narrow particle size distribution without any aggregation. The difference between $D_{\mathrm{h}}$ values and diameters calculated from TEM micrographs (Table 1) comes from the fact that direct measurement on TEM yields number-averaged diameters of dried particles $\left(D_{\mathrm{n}}\right)$, while DLS yields intensityaveraged diameters of hydrated particles $\left(D_{\mathrm{h}}\right)$, which overestimates bigger particles and thus is sensitive to even a small amount of aggregates. Moreover, magnetic nanoparticles prepared by thermal decomposition in organic media adsorbed OA stabilizer on their surfaces, which also contributes to increased $D_{\mathrm{h}}$; however, since the OA molecules have low atomic numbers in comparison with the iron oxide, they are not visible in the TEM micrographs. It should also be noted that $\mathrm{Fe}_{3} \mathrm{O}_{4}$ particles with $D_{\mathrm{n}}<20 \mathrm{~nm}$ exhibited superparamagnetic behavior. ${ }^{42}$ That means that in the absence of an external magnetic field, the particles are dispersed in a solvent forming a colloid; however, they can be attracted by a magnet and

Table 1 Characterization of the $\mathrm{Fe}_{3} \mathrm{O}_{4}$ nanoparticles by $\mathrm{TEM}^{a}$

\begin{tabular}{|c|c|c|c|c|c|}
\hline No. & Nanoparticles & $\mathrm{TMOS} / \mathrm{Fe}_{3} \mathrm{O}_{4}\left(\mu \mathrm{L} \mathrm{mg}{ }^{-1}\right)$ & $D_{\mathrm{n}}(\mathrm{nm})$ & PDI & $\mathrm{SiO}_{2}$ thickness (nm) \\
\hline I & $\mathrm{Fe}_{3} \mathrm{O}_{4}$ & - & 6 & 1.01 & - \\
\hline $\mathrm{I} / 1$ & $\mathrm{Fe}_{3} \mathrm{O}_{4} \& \mathrm{SiO}_{2}$ & $40 / 30$ & 12 & 1.05 & 3 \\
\hline $\mathrm{I} / 2$ & $\mathrm{Fe}_{3} \mathrm{O}_{4} \& \mathrm{SiO}_{2}$ & $80 / 30$ & 14 & 1.03 & 4 \\
\hline $\mathrm{I} / 3$ & $\mathrm{Fe}_{3} \mathrm{O}_{4} \& \mathrm{SiO}_{2}$ & $120 / 30$ & 16 & 1.02 & 5 \\
\hline II & $\mathrm{Fe}_{3} \mathrm{O}_{4}$ & - & 10 & 1.01 & - \\
\hline $\mathrm{II} / 1$ & $\mathrm{Fe}_{3} \mathrm{O}_{4} \& \mathrm{SiO}_{2}$ & $40 / 10$ & 28 & 1.01 & 9 \\
\hline $\mathrm{II} / 2$ & $\mathrm{Fe}_{3} \mathrm{O}_{4} \& \mathrm{SiO}_{2}$ & $40 / 30$ & 28 & 1.01 & 9 \\
\hline II $/ 3$ & $\mathrm{Fe}_{3} \mathrm{O}_{4} \& \mathrm{SiO}_{2}$ & $40 / 80$ & 18 & 1.01 & 4 \\
\hline $\mathrm{II} / 4$ & $\mathrm{Fe}_{3} \mathrm{O}_{4} \& \mathrm{SiO}_{2}$ & $20 / 30$ & 20 & 1.01 & 5 \\
\hline $\mathrm{II} / 5$ & $\mathrm{Fe}_{3} \mathrm{O}_{4} \& \mathrm{SiO}_{2}$ & $60 / 30$ & 36 & 1.02 & 13 \\
\hline III & $\mathrm{Fe}_{3} \mathrm{O}_{4}$ & - & 20 & 1.01 & - \\
\hline $\mathrm{III} / 1$ & $\mathrm{Fe}_{3} \mathrm{O}_{4} \& \mathrm{SiO}_{2}$ & $50 / 30$ & 25 & 1.02 & 2.5 \\
\hline $\mathrm{III} / 2$ & $\mathrm{Fe}_{3} \mathrm{O}_{4} \& \mathrm{SiO}_{2}$ & $120 / 30$ & 28 & 1.01 & 4 \\
\hline III $/ 3$ & $\mathrm{Fe}_{3} \mathrm{O}_{4} \& \mathrm{SiO}_{2}$ & $150 / 30$ & 30 & 1.01 & 5 \\
\hline
\end{tabular}

${ }^{a}$ TMOS - tetramethyl orthosilicate; $D_{\mathrm{n}}$ - number-averaged diameter; PDI - polydispersity index. 

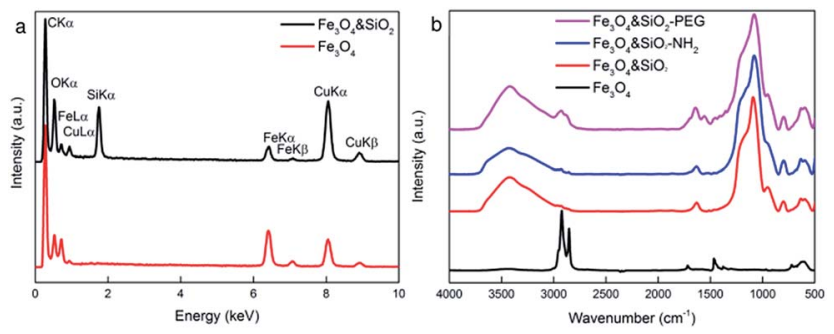

Fig. 3 (a) TEM/EDX and (b) ATR FTIR spectra of starting and surfacemodified $\mathrm{Fe}_{3} \mathrm{O}_{4}$ nanoparticles.

magnetically manipulated. Moreover, such a small particle size is convenient for future applications as it avoids particle clearance by the liver and spleen. The magnetic properties of $\mathrm{Fe}_{3} \mathrm{O}_{4}$ nanoparticles prepared by thermal decomposition of $\mathrm{Fe}(\mathrm{III})$ oleate were described in our earlier publication. ${ }^{26}$

The structure of the $\mathrm{Fe}_{3} \mathrm{O}_{4}$ nanoparticles was analyzed by ATR FTIR spectroscopy (Fig. 3b). Characteristic bands of asymmetric and symmetric $\mathrm{CH}_{2}$ stretching vibrations of $\mathrm{OA}$ were observed at 2920 and $2852 \mathrm{~cm}^{-1}$, respectively, and the peak between 595 and $630 \mathrm{~cm}^{-1}$ was ascribed to $\mathrm{Fe}-\mathrm{O}$ vibrations.

\subsection{Surface modification of $\mathrm{Fe}_{3} \mathrm{O}_{4}$ with silica}

OA-stabilized $\mathrm{Fe}_{3} \mathrm{O}_{4}$ particles have the disadvantage that they are hydrophobic. To transfer such particles in water, in which all biological experiments are performed, it is necessary to modify their surface with a hydrophilic compound, such as $\mathrm{SiO}_{2}$. Hence, the starting $\mathrm{Fe}_{3} \mathrm{O}_{4}$ nanoparticles were coated with a silica shell by a water-in-oil (w/o) reverse microemulsion method. The reaction is based on the ammonia-catalyzed hydrolysis of TMOS and the condensation of hydrolyzed silica species. The thickness of the silica layer on the particles, which is determinative for internalization in the cells, depends on the concentrations of the starting nanoparticles, silane precursor (TMOS), catalyst (ammonia), and surfactant (Igepal CO-520). ${ }^{43}$ The silica thickness was thus controlled by changing the $\mathrm{TMOS} / \mathrm{Fe}_{3} \mathrm{O}_{4}$ ratio in the synthesis, which regulates the degree of hydrolysis and condensation, as well as influencing the particle growth.

In the first set of experiments, the optimal iron oxide concentration was determined, that led to formation of coreshell particles with properties satisfying all the requirements imposed on the resulting product. These include formation of homogeneous and robust silica shells around the particles without production of any additional neat silica. The $\mathrm{Fe}_{3} \mathrm{O}_{4}$ content in the reaction feed was changed at a constant amount of hexane, $\mathrm{NH}_{4} \mathrm{OH}$, Igepal CO-520, and TMOS.

When investigating the effect of the $\mathrm{TMOS} / \mathrm{Fe}_{3} \mathrm{O}_{4}$ ratio on the particle size and size distribution, the optimal ratio for formation of uniform silica shells on $\mathrm{Fe}_{3} \mathrm{O}_{4}$ particles No. II was found to be $40 \mu \mathrm{L} / 30 \mathrm{mg}$ (No. II/2 in Table 1; Fig. 2b). At the ratio $=40$ $\mu \mathrm{L} / 10 \mathrm{mg}$, neat silica particles were also produced (No. II/1 in Table 1; Fig. 2a), while at $40 \mu \mathrm{L}$ of TMOS/80 mg Fe $\mathrm{O}_{4}$, inhomogeneous silica shells were formed on the particles (No. II/3 in Table 1; Fig. 2c).
In the second set of experiments, the volume of TMOS in the reaction was varied to control the silica shell thickness on the particles No. I-III, while the other reactants $\left(\mathrm{Fe}_{3} \mathrm{O}_{4}\right.$, hexane, $\mathrm{NH}_{4} \mathrm{OH}$, and Igepal CO-520) were kept constant. TEM/EDX measurements proved the presence of silica (Fig. 3a). The silica shell thickness increased from 3 to 5 , from 5 to 13 , and from 2.5 to $5 \mathrm{~nm}$ with $\mathrm{TMOS} / \mathrm{Fe}_{3} \mathrm{O}_{4}$ ratios increasing from $40 / 30$ to $120 / 30$, from $20 / 30$ to $60 / 30$, and from $50 / 30$ to $150 / 30(\mu \mathrm{L}$ $\mathrm{mg}^{-1}$ ), respectively (Fig. 2, Table 1). The TEM/EDX spectrum of $\mathrm{Fe}_{3} \mathrm{O}_{4} \& \mathrm{SiO}_{2}$ particles exhibited strong $\mathrm{Si}$ peak, while the remaining peaks in the spectra of both $\mathrm{Fe}_{3} \mathrm{O}_{4}$ and $\mathrm{Fe}_{3} \mathrm{O}_{4} \& \mathrm{SiO}_{2}$ particles belonged to magnetite $(\mathrm{Fe}, \mathrm{O})$ and the supporting carbon-coated copper grid (C, Cu; Fig. 3a). The $\mathrm{Fe}_{3} \mathrm{O}_{4} \& \mathrm{SiO}_{2}$ nanoparticles demonstrated colloidal stability $\left(D_{\mathrm{h}}=114 \mathrm{~nm}\right.$, $\mathrm{PD}=0.14)$ and negative surface charge $(-30 \mathrm{mV})$ due to the presence of silanol groups on the particle surfaces.

The ATR FTIR spectrum of $\mathrm{Fe}_{3} \mathrm{O}_{4} \& \mathrm{SiO}_{2}$ confirmed the presence of $\mathrm{SiO}_{2}$ shells around the particles, as documented by intensive bands at 950 and $1080 \mathrm{~cm}^{-1}$ (Fig. 3b) ascribed to the symmetric and asymmetric stretching vibrations of $\mathrm{Si}-\mathrm{OH}$ and $\mathrm{Si}-\mathrm{O}-\mathrm{Si}$, respectively, while the OA peaks completely vanished. To further functionalize $\mathrm{Fe}_{3} \mathrm{O}_{4} \& \mathrm{SiO}_{2}$ particles, their surfaces were modified by amino groups by reaction with APTES. In the IR spectrum of the $\mathrm{Fe}_{3} \mathrm{O}_{4} \& \mathrm{SiO}_{2}-\mathrm{NH}_{2}$ nanoparticles, no significant changes were detected compared to the $\mathrm{Fe}_{3} \mathrm{O}_{4} \& \mathrm{SiO}_{2}$ spectrum probably due to the detection limits of the ATR technique. Intense broad peaks at $\sim 3430$ and $1630 \mathrm{~cm}^{-1}$ were attributed to $\mathrm{OH}$ stretching and bending vibrations of adsorbed water.

$\mathrm{Fe}_{3} \mathrm{O}_{4} \& \mathrm{SiO}_{2}-\mathrm{NH}_{2}$ particles had a rather low positive charge $(12 \mathrm{mV})$, which was not sufficient for efficient colloidal stability; $D_{\mathrm{h}}=210 \mathrm{~nm}$ and $\mathrm{PD}=0.25$ documented the tendency of these particles to form aggregates. ${ }^{44}$

\subsection{Surface modification of $\mathrm{Fe}_{3} \mathrm{O}_{4} \& \mathrm{SiO}_{2}$ nanoparticles with PEG}

To minimize the toxicity of the silica-coated particles and to render them invisible to the reticuloendothelial system, i.e., to prevent their uptake by different cell types (macrophages and NSCs) and to increase the blood circulation time, the $\mathrm{Fe}_{3} \mathrm{O}_{4} \&$ $\mathrm{SiO}_{2}-\mathrm{NH}_{2}$ nanoparticles were modified with PEG, which is wellknown for hydrophilicity and nonionogenicity, ${ }^{25}$ by reaction with its succinimidyl ester. The modification was documented by DLS and ATR FTIR spectroscopy. The $\mathrm{Fe}_{3} \mathrm{O}_{4} \& \mathrm{SiO}_{2}$-PEG nanoparticles demonstrated good colloidal stability $\left(D_{\mathrm{h}}=\right.$ $43 \mathrm{~nm}, \mathrm{PD}=0.20$ ), although the total negative surface charge was relatively low $(-5 \mathrm{mV})$. ATR FTIR spectroscopy of the $\mathrm{Fe}_{3}{ }^{-}$ $\mathrm{O}_{4} \& \mathrm{SiO}_{2}$-PEG nanoparticles revealed new intensive peaks at 2925 and $2850 \mathrm{~cm}^{-1}$, which were attributed to the asymmetric and symmetric stretching $\mathrm{CH}_{2}$ vibrations (Fig. $3 \mathrm{~b}$ ).

\subsection{Labelling efficiency and uptake of $\mathrm{Fe}_{3} \mathrm{O}_{4} \& \mathrm{SiO}_{2}$ and $\mathrm{Fe}_{3} \mathrm{O}_{4} \& \mathrm{SiO}_{2}$-PEG nanoparticles by murine neural stem cells}

Superparamagnetic iron oxide nanoparticles are one of the most promising tools for labelling and tracking various cells by MRI. ${ }^{45,46}$ The labelling efficiency and cellular uptake of $\mathrm{Fe}_{3}$ $\mathrm{O}_{4} \& \mathrm{SiO}_{2}$ and $\mathrm{Fe}_{3} \mathrm{O}_{4} \& \mathrm{SiO}_{2}$-PEG nanoparticles were evaluated by 


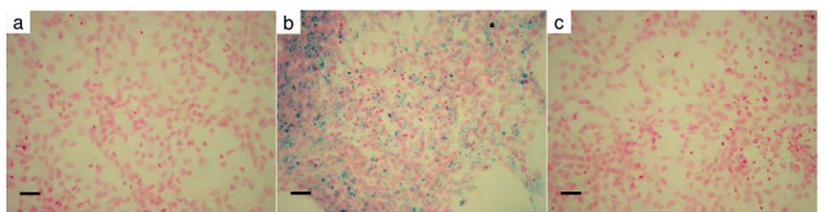

Fig. 4 Light micrographs of Prussian blue-stained (a) unlabeled, (b) $\mathrm{Fe}_{3} \mathrm{O}_{4} \& \mathrm{SiO}_{2}^{-}$, and (c) $\mathrm{Fe}_{3} \mathrm{O}_{4} \& \mathrm{SiO}_{2}-\mathrm{PEG}$-labeled mNSCs (20 $\mu \mathrm{g}$ of particle per $\mathrm{mL}$ ) for $24 \mathrm{~h}$. Nuclear fast red staining showed the nuclei. Scale bar $50 \mu \mathrm{m}$.

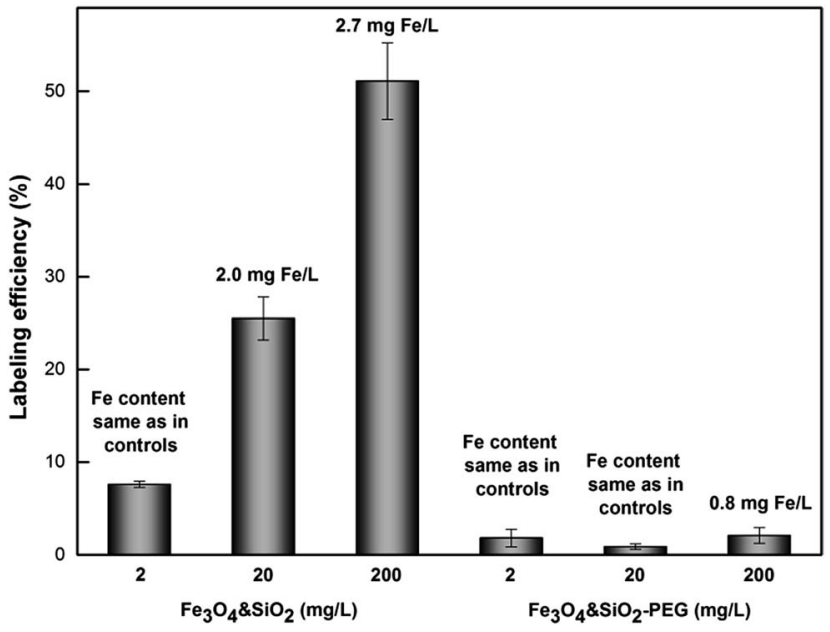

Fig. 5 Labeling efficiency of $\mathrm{mNSCs}$ by $\mathrm{Fe}_{3} \mathrm{O}_{4} \& \mathrm{SiO}_{2}$ and $\mathrm{Fe}_{3} \mathrm{O}_{4} \& \mathrm{SiO}_{2}-$ PEG nanoparticles analyzed by flow cytometry. mNSCs were exposed to different concentrations of particles for $24 \mathrm{~h}$. Labeling efficiency, expressed as the mean of three independent experiments conducted in 5 replicates, was calculated as the percentage of the increase of the side-scattered light of the laser beam (SSC) relative to negative controls. Error bars represent standard deviations. Fe content in mNSCs was measured by ICP-MS. Non-treated cells (control) contained $0.23 \pm 0.03 \mathrm{mg}$ Fe per $\mathrm{L}$.

Prussian blue staining, flow cytometry, quantitative ICP-MS determination of total Fe cellular content, and TEM.

The simple method of Prussian blue staining demonstrated that $\mathrm{Fe}_{3} \mathrm{O}_{4} \& \mathrm{SiO}_{2}$-PEG nanoparticles were not taken up by the mNSCs and labelling was very efficient with $\mathrm{Fe}_{3} \mathrm{O}_{4} \& \mathrm{SiO}_{2}$ (Fig. 4). Flow cytometry and TEM confirmed these results and clearly showed that mNSCs did not internalize a significant amount of $\mathrm{Fe}_{3} \mathrm{O}_{4} \& \mathrm{SiO}_{2}$-PEG nanoparticles (Fig. 5 and 6). The uptake of $\mathrm{Fe}_{3} \mathrm{O}_{4} \& \mathrm{SiO}_{2}$ was dose-dependent. Moreover, $\mathrm{Fe}_{3} \mathrm{O}_{4} \& \mathrm{SiO}_{2}$ labelled more than $50 \%$ of the mNSC population at a 20 -fold lower concentration $\left(200 \mathrm{mg} \mathrm{L}^{-1}\right)$ than commercial dextrancoated nanomag( ${ }^{\circledR}$-D-spio particles. ${ }^{27}$ TEM images clearly demonstrated that $\mathrm{Fe}_{3} \mathrm{O}_{4} \& \mathrm{SiO}_{2}$ particles were located both in the cytoplasm and membrane-bound vesicles after uptake into mNSCs (Fig. 6c and d).

\subsection{Biocompatibility and biosafety evaluation of $\mathrm{Fe}_{3} \mathrm{O}_{4} \& \mathrm{SiO}_{2}$ and $\mathrm{Fe}_{3} \mathrm{O}_{4} \& \mathrm{SiO}_{2}$-PEG nanoparticles}

The unique and desirable specific features of superparamagnetic nanoparticles may potentially induce cytotoxic effects and should

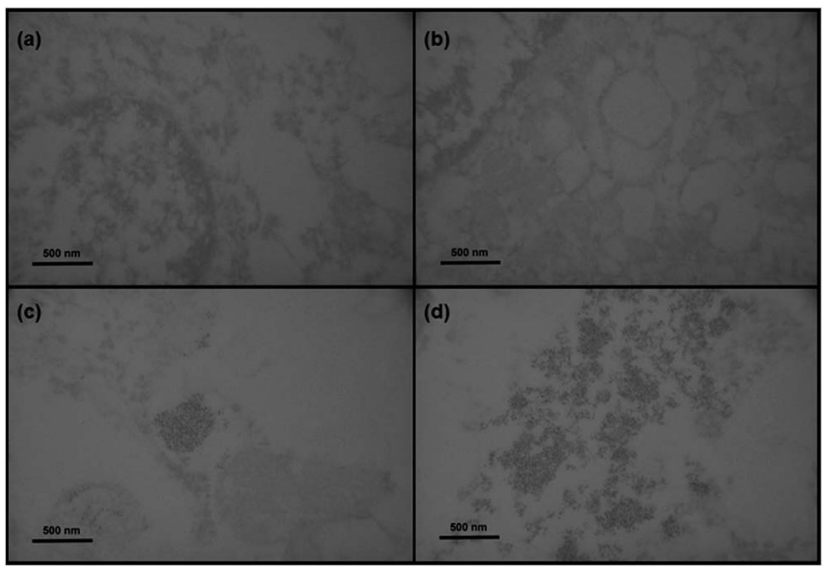

Fig. 6 TEM micrographs of (a) non-treated mNSCs (control), (b) mNSCs treated with $\mathrm{Fe}_{3} \mathrm{O}_{4} \& \mathrm{SiO}_{2}$-PEG (no nanoparticles detected) for $24 \mathrm{~h}$, (c) dispersed and agglomerated $\mathrm{Fe}_{3} \mathrm{O}_{4} \mathrm{gSiO} 2$ in a large endosome, and (d) agglomerated $\mathrm{Fe}_{3} \mathrm{O}_{4} \& \mathrm{SiO}_{2}$ in cytoplasm

be evaluated for each novel particle type, addressing biocompatibility and biosafety concerns associated with their usage. ${ }^{38}$ $\mathrm{Fe}_{3} \mathrm{O}_{4} \& \mathrm{SiO}_{2}$ nanoparticles were found in endosomes of mNSCs (Fig. 6), assuming the transfer of particles to lysosomes and the release of free iron ions into the cell cytoplasm after lysosomal degradation. ${ }^{47,48}$ In the cytosol, nanoparticle-derived Fe ions are stored in ferritin, catalyze ROS generation and/or are used for Fedependent cellular processes. ${ }^{49}$

In this study, the response of mNSCs to treatment with $\mathrm{Fe}_{3} \mathrm{O}_{4} \& \mathrm{SiO}_{2}$ and $\mathrm{Fe}_{3} \mathrm{O}_{4} \& \mathrm{SiO}_{2}$-PEG nanoparticles was evaluated by determination of cytotoxicity. This included cell viability and survival/mortality tests and investigation of oxidative stress, i.e., production of ROS, and study of changes in intracellular GSH levels and mitochondrial membrane potential. $\mathrm{Fe}_{3} \mathrm{O}_{4} \& \mathrm{SiO}_{2}$-PEG nanoparticles, which were not actually taken up by the cells, had no cytotoxic effect (Fig. 7). Even the highest concentration (200 $\mathrm{mg} \mathrm{L}^{-1}$ ) of $\mathrm{Fe}_{3} \mathrm{O}_{4} \& \mathrm{SiO}_{2}$-PEG nanoparticles did not significantly affect either the survival or viability of mNSCs.

For $\mathrm{Fe}_{3} \mathrm{O}_{4} \& \mathrm{SiO}_{2}$ particles, only their lowest concentrations had no influence on the survival and viability of mNSCs. When the lowest possible concentration to achieve efficient cell labelling $\left(20 \mathrm{mg} \mathrm{L}^{-1}\right)$ was used, $\mathrm{Fe}_{3} \mathrm{O}_{4} \& \mathrm{SiO}_{2}$ particles decreased cell viability by more than $50 \%$ compared to the control, while cell mortality increased by less than $20 \%$ (Fig. 7). It is interesting to note that the survival of mNSCs treated with $200 \mathrm{mg}$ of $\mathrm{Fe}_{3} \mathrm{O}_{4} \& \mathrm{SiO}_{2}$ per $\mathrm{L}$ was $c a .50 \%$ compared to the control (Fig. 7), while the same concentration of $\mathrm{Fe}_{3} \mathrm{O}_{4} \& \mathrm{SiO}_{2}$ labelled $c a$. $50 \%$ of live cells (Fig. 5). This means that the number of labelled mNSCs was almost the same for 20 and $200 \mathrm{mg}$ of $\mathrm{Fe}_{3} \mathrm{O}_{4} \& \mathrm{SiO}_{2}$ per $\mathrm{L}$, indicating that the optimal particle dose for stem cell labelling was 20 rather than $200 \mathrm{mg} \mathrm{L}^{-1}$. This was also supported by ICP-MS determination of the total Fe content in treated compared to control mNSCs (Fig. 5). A ten-fold increase in $\mathrm{Fe}_{3} \mathrm{O}_{4} \& \mathrm{SiO}_{2}$ concentration applied to mNSCs, i.e., from 20 to $200 \mathrm{mg} \mathrm{L}^{-1}$, did not proportionally increase the $\mathrm{Fe}$ content in the cells. As expected, Fe levels in mNSCs treated with $\mathrm{Fe}_{3} \mathrm{O}_{4} \&-$ $\mathrm{SiO}_{2}$-PEG nanoparticles were similar to those in the control cells $(\sim 0.23 \mathrm{mg}$ Fe per $\mathrm{L})$. However, the increased value $(0.8 \mathrm{mg} \mathrm{Fe}$ 


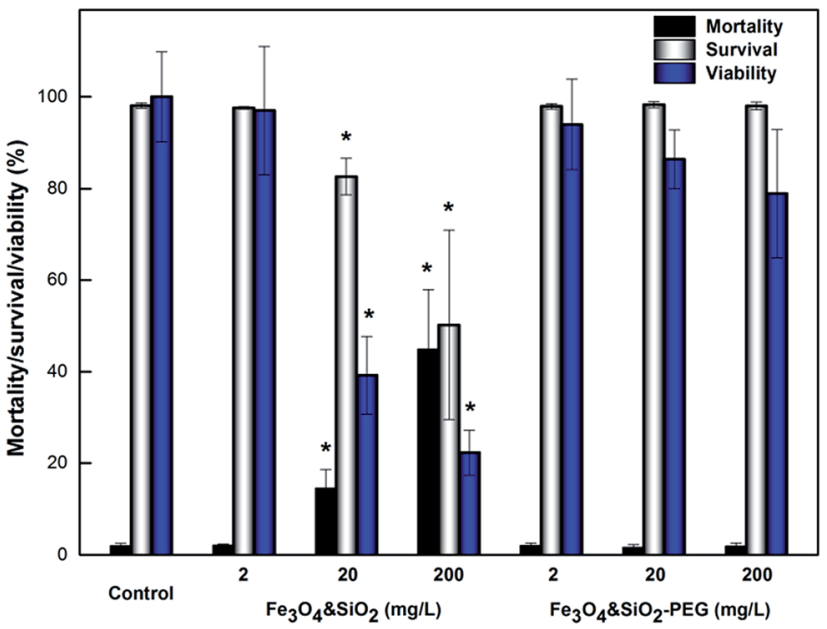

Fig. 7 Effect of different concentrations of $\mathrm{Fe}_{3} \mathrm{O}_{4} \& \mathrm{SiO}_{2}$ nanoparticles on mortality, survival, and viability of $\mathrm{mNSCs}$ relative to control after $24 \mathrm{~h}$ exposure. Control cells were cultivated in particle-free exposure media. Cell viability was measured by the MTT assay. Cell survival/ mortality was determined by flow cytometry. All data, calculated as percentages of the values in control cells, were expressed as the mean of three independent experiments conducted in five replicates. Error bars represent standard deviations. * - statistically significant difference $(P<0.05)$ versus control.

per L) in cells treated with $200 \mathrm{mg}$ of $\mathrm{Fe}_{3} \mathrm{O}_{4} \& \mathrm{SiO}_{2}$-PEG per $\mathrm{L}$ indicated that some nanoparticles were strongly attached to the cell surface.

Oxidative stress in mNSCs treated with $\mathrm{Fe}_{3} \mathrm{O}_{4} \& \mathrm{SiO}_{2}$ and $\mathrm{Fe}_{3} \mathrm{O}_{4} \& \mathrm{SiO}_{2}$-PEG nanoparticles was evaluated using DCFH-DA, $\mathrm{MBCl}$, and $\mathrm{DiOC}_{6}$ fluorescent dyes (Fig. 8). The ROS level significantly increased after a $4 \mathrm{~h}$ treatment of mNSCs at 20 and $200 \mathrm{mg}$ of $\mathrm{Fe}_{3} \mathrm{O}_{4} \& \mathrm{SiO}_{2}$ per $\mathrm{L}$, while the increase was significant only for the highest concentration of $\mathrm{Fe}_{3} \mathrm{O}_{4} \& \mathrm{SiO}_{2}$-PEG (Fig. 8). These results clearly showed that disturbances in cell functions leading to ROS production may occur either upon internalization of the nanoparticles or even upon contact with them.

The response of mNSCs to treatment with $\mathrm{Fe}_{3} \mathrm{O}_{4} \& \mathrm{SiO}_{2}$ and $\mathrm{Fe}_{3} \mathrm{O}_{4} \& \mathrm{SiO}_{2}$-PEG nanoparticles was further evaluated by using the major endogenous antioxidant scavenger, GSH, as a biomarker. ${ }^{50}$ An alteration in the GSH level is an elegant direct measure for the adaptive cellular response to oxidative damage. ${ }^{51}$ Significant depletion of GSH in mNSCs was observed for the highest dose of $\mathrm{Fe}_{3} \mathrm{O}_{4} \& \mathrm{SiO}_{2}$, whereas all doses of $\mathrm{Fe}_{3} \mathrm{O}_{4} \& \mathrm{SiO}_{2}$-PEG particles caused the opposite effect, i.e., a significant increase in the GSH level after $4 \mathrm{~h}$ (Fig. 8). These observations revealed that mNSCs activated antioxidative defense mechanisms when exposed to $\mathrm{Fe}_{3} \mathrm{O}_{4} \& \mathrm{SiO}_{2}$ and $\mathrm{Fe}_{3} \mathrm{O}_{4} \& \mathrm{SiO}_{2}$-PEG nanoparticles. Depletion in GSH levels is considered an indirect measure for persistent oxidative stress caused by efficient degradation of the ROS, while increased GSH indicates triggering of a preventive cellular mechanism at an early stage of redox stress.

Measurements of changes in the mitochondrial membrane potential (MMP) provided additional evidence of oxidative stress response in mNSCs by $\mathrm{Fe}_{3} \mathrm{O}_{4} \& \mathrm{SiO}_{2}$ and $\mathrm{Fe}_{3} \mathrm{O}_{4} \& \mathrm{SiO}_{2}$-PEG nanoparticles (Fig. 8). Redox stress may perturb mitochondrial

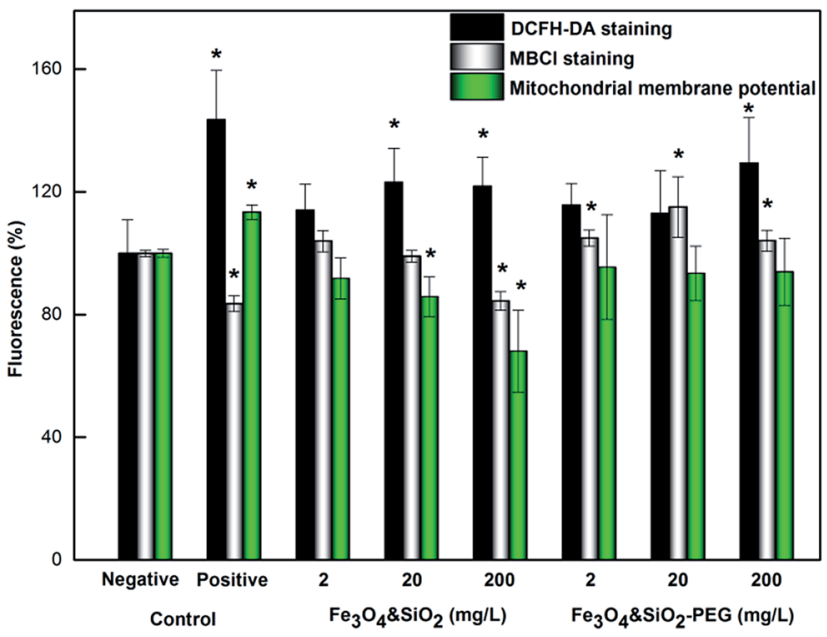

Fig. 8 Effect of $\mathrm{Fe}_{3} \mathrm{O}_{4} \& \mathrm{SiO}_{2}$ and $\mathrm{Fe}_{3} \mathrm{O}_{4} \& \mathrm{SiO}_{2}-\mathrm{PEG}$ nanoparticles on the levels of reactive oxygen species (measured by DCFH-DA staining), GSH (measured by $\mathrm{MBCl}$ staining), and changes in mitochondrial membrane potentials (measured by $\mathrm{DiOC}_{6}$ staining) in mNSCs. Cells were exposed to different concentrations of nanoparticles for $4 \mathrm{~h}$. Negative control cells were cultivated in nanoparticle-free exposure media, and positive controls were treated with $100 \mu \mathrm{M}$ hydrogen peroxide. The data, expressed as the mean of three independent experiments conducted in five replicates, were calculated as percentages relative to negative controls. Error bars represent standard deviations. * - statistically significant difference $(P<0.05)$ compared to negative controls.

function in several ways, including dissipation or an increase in MMP. Changes in MMP were measured using the voltagedependent dye DiOC $_{6}$ in non-quenching mode at a nanomolar concentration. In addition, treatment of mNSCs was performed before staining. Using this experimental setup, a decrease in dye fluorescence compared to control cells implies depolarized (less negative) mitochondria, which took a lower amount of dye. In contrast, higher fluorescence in treated compared to control cells refers to hyperpolarized (more negative) mitochondria. Treatment of mNSCs with $\mathrm{Fe}_{3} \mathrm{O}_{4} \& \mathrm{SiO}_{2}$ for $4 \mathrm{~h}$ induced a dosedependent decrease in MMP compared to control cells (Fig. 8), thus leading to the mitochondrial depolarization. Only the lowest dose of $\mathrm{Fe}_{3} \mathrm{O}_{4} \& \mathrm{SiO}_{2}$ did not induce significant mitochondrial depolarization. Similar behavior has already been described for cells exposed to magnetite nanoparticles. ${ }^{52}$ It is well-known that dissipation of MMP can be associated with ROS production and may be a prerequisite step for cell death by apoptosis or necrosis. ${ }^{53}$ As expected, $\mathrm{Fe}_{3} \mathrm{O}_{4} \& \mathrm{SiO}_{2}$-PEG nanoparticles, which were not internalized in the cells, did not significantly change MMP. In contrast, treatment of mNSCs with hydrogen peroxide as the positive control (Fig. 6) caused mitochondrial membrane hyperpolarization in mNSCs, as described previously. ${ }^{38}$ Again, similarly to the uncoated, $\mathrm{D}^{-}$ mannose-, and poly(L-lysine)-coated maghemite nanoparticles, ${ }^{38}$ our results showed that iron oxides may perturb cellular functions. Here, it was clearly demonstrated that surface coating has an important role in the design of nanoparticles enabling different modalities of biocompatibility and applicability in medicine. 
Table $2 T_{1}, T_{2}$, and $T_{2}^{*}$ relaxation times of $\mathrm{Fe}_{3} \mathrm{O}_{4} \& \mathrm{SiO}_{2}$ and $\mathrm{Fe}_{3} \mathrm{O}_{4} \& \mathrm{SiO}_{2}-\mathrm{PEG}$ nanoparticles suspended in 20 vol\% glycerol

\begin{tabular}{lllll}
\hline Particles & Concentration $\left(\mathrm{mg} \mathrm{L}^{-1}\right)$ & $T_{1}(\mathrm{~ms})$ & $T_{2}(\mathrm{~ms})$ & $T_{2}^{*}(\mathrm{~ms}) / \mathrm{HPBW}(\mathrm{Hz})$ \\
\hline $\mathrm{Fe}_{3} \mathrm{O}_{4} \& \mathrm{SiO}_{2}$-PEG & 0 (native) & $1605 \pm 8$ & $46.7 \pm 0.3$ & $16.7 \pm 1.7 / 20$ \\
& 10 & $1630 \pm 13$ & $28.8 \pm 0.1$ & $13.0 \pm 1.0 / 29$ \\
& 40 & $1655 \pm 8$ & $13.1 \pm 0.1$ & $<10^{a}$ \\
$\mathrm{Fe}_{3} \mathrm{O}_{4} \& \mathrm{SiO}_{2}$ & 100 & $1621 \pm 19$ & $47.8 \pm 0.3$ & $<10 / 55^{a}$ \\
& 0 (native) & $1610 \pm 6$ & $27.6 \pm 0.1$ & $22.6 \pm 0.5 / 20$ \\
& 10 & $1633 \pm 4$ & $14.3 \pm 0.1$ & $<10^{a}$
\end{tabular}

${ }^{a}$ The value was outside the reliable fitting range of the measurement; HPBW - half-power bandwidth.

\subsection{MRI validation of $\mathrm{Fe}_{3} \mathrm{O}_{4} \& \mathrm{SiO}_{2}$ and $\mathrm{Fe}_{3} \mathrm{O}_{4} \& \mathrm{SiO}_{2}$-PEG nanoparticle visibility in mouse brain ex vivo}

Phantom MRI measurements. MR relaxometry on phantoms determined the concentration of particles required for sufficient MR contrast in the ex vivo setting of a mouse brain. Based on the measured relaxation times of phantoms and typical relaxation times of brain tissue in vivo, ${ }^{54}$ the minimal concentration of both $\mathrm{Fe}_{3} \mathrm{O}_{4} \& \mathrm{SiO}_{2}$ and $\mathrm{Fe}_{3} \mathrm{O}_{4} \& \mathrm{SiO}_{2}$-PEG nanoparticles ensuring sufficient contrast in in vivo/ex vivo conditions was estimated to be $40 \mathrm{mg} \mathrm{L}{ }^{-1}$. The relaxation times of particledoped phantom loads are given in Table 2. As expected for a low iron oxide dosage,$^{55}$ there was no significant impact of the nanoparticles on the $T_{1}$ relaxation time regardless of tested particle concentration, while a pronounced effect on the $T_{2}$ relaxation time and an even stronger effect on the $T_{2}^{*}$ relaxation time were observed (Table 2). It should be noted, however, that $T_{2}^{*}$ values are not a measure of tissue relaxation only, but of the local field homogeneity as well, which in turn depends on the quality of shimming and can vary in the same sample from one scan session to another. ${ }^{55}$ The worse the shimming, the shorter the $T_{2}^{*}$ time. Thus, the $T_{2}^{*}$ values (Table 2) are not to be taken as absolute reference values; rather, their purpose is to provide the basis for estimating the minimal particle concentration for

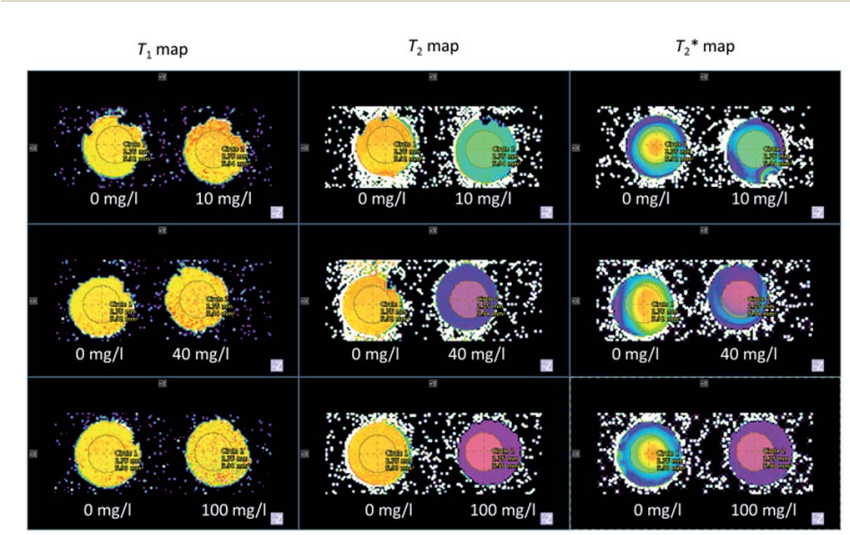

Fig. 9 Maps of measured $T_{1}, T_{2}$, and $T_{2}^{*}$ relaxation times for 10 (top row), 40 (middle row), and $100 \mathrm{mg}$ of $\mathrm{Fe}_{3} \mathrm{O}_{4} \& \mathrm{SiO}_{2}-\mathrm{PEG}$ particles per $\mathrm{L}$ of 20 vol\% glycerol (bottom row). The uneven color in $T_{2}^{*}$ maps reflects local magnetic field inhomogeneity that shimming was unable to correct for. sufficient contrast and reliable MRI detection in in vivo/ex vivo conditions. A $T_{2} / T_{2}^{*}$ value around one half of the typical $T_{2} / T_{2}^{*}$ of the surrounding tissue in a given application should be sufficient to produce negative contrast in $T_{2}$ - and $T_{2}^{*}$-weighted images, even if the injected particles spread over a larger volume. Depending on the application and the injected contrast agent volume, the concentration may be even lower. For comparison, typical $T_{2}$ times in a mouse brain in vivo are approximately 35-40 ms when measured in a 7 Tesla instrument, ${ }^{54}$ while $T_{2}^{*}$ times are shorter, typically $15-20 \mathrm{~ms}$. Thus, a measured $T_{2}$ and $T_{2}^{*} \leq 20$ and $10 \mathrm{~ms}$, respectively, on a phantom are reliable indicators of the required MRI visibility of magnetic particles in the mouse brain.

The effect of increasing $\mathrm{Fe}_{3} \mathrm{O}_{4} \& \mathrm{SiO}_{2}$-PEG particle concentration in $20 \mathrm{vol} \%$ glycerol on the negative contrast is illustrated in Fig. 9. Similar behavior was observed for $\mathrm{Fe}_{3} \mathrm{O}_{4} \& \mathrm{SiO}_{2}$ nanoparticles (Table 2). The effect of shimming on the $T_{2}^{*}$ relaxation time is visible in the rightmost column representing $T_{2}^{*}$ maps, where the particle-doped phantom did not display steady values across the whole cross-section of the tube, unlike in the $T_{1}$ and $T_{2}$
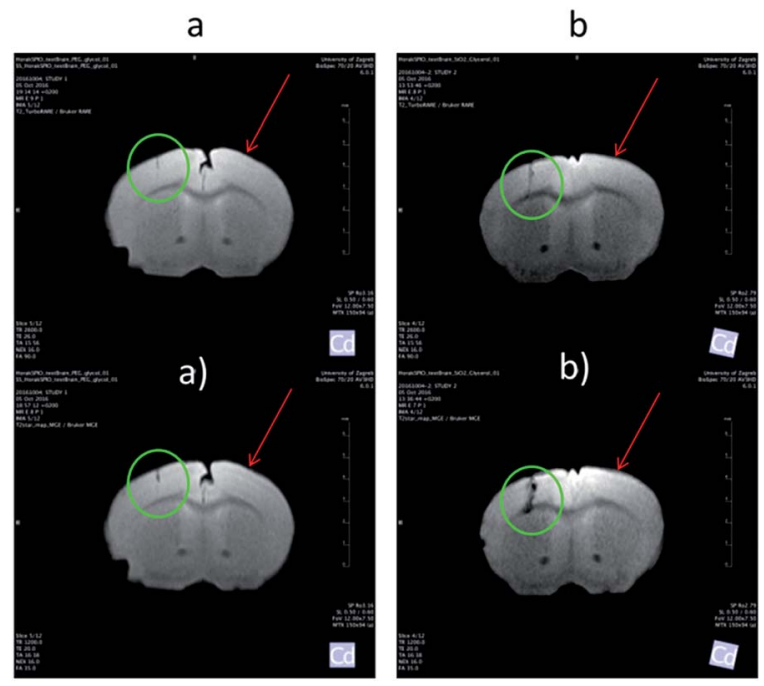

Fig. $10 T_{2^{-}}$(top row) and $T_{2}^{*}$-weighted images (bottom row) of adult mouse brain ex vivo with (a) $\mathrm{Fe}_{3} \mathrm{O}_{4} \& \mathrm{SiO}_{2}-\mathrm{PEG}$ and (b) $\mathrm{Fe}_{3} \mathrm{O}_{4} \& \mathrm{SiO}_{2}$ nanoparticles injected on the left side and control host medium (20 vol\% glycerol) injected on the right side. 
maps. This effect was augmented for higher particle concentrations, as the decreased relaxation time resulted in reduced signal strength, thus making good shimming much harder to realize.

\subsection{MRI visualization of $\mathrm{Fe}_{3} \mathrm{O}_{4} \& \mathrm{SiO}_{2}$ and $\mathrm{Fe}_{3} \mathrm{O}_{4} \& \mathrm{SiO}_{2}$-PEG nanoparticles in mouse brain ex vivo}

Both $\mathrm{Fe}_{3} \mathrm{O}_{4} \& \mathrm{SiO}_{2}$ and $\mathrm{Fe}_{3} \mathrm{O}_{4} \& \mathrm{SiO}_{2}$-PEG nanoparticles $(40 \mathrm{mg}$ $\mathrm{L}^{-1}$ ) were clearly visible in MRI images, as seen from the comparison between the $T_{2}$ - and $T_{2}^{*}$-weighted images of adult mouse brain ex vivo with injected particles (Fig. 10). As expected, the contrast was much more pronounced in the $T_{2}^{*}$-weighted images. The contrast created by iron oxide particles in the surrounding tissue results from the fact that the iron oxide core disturbs the local magnetic field creating magnetic inhomogeneity, to which acquisition schemes based on gradient echo sequences (for $T_{2}^{*}$-weighting) are much more susceptible. ${ }^{55}$

\section{Conclusions}

$\mathrm{Fe}_{3} \mathrm{O}_{4}$ nanoparticles with uniform size and well-defined spherical shape were synthetized by thermal decomposition of $\mathrm{Fe}$ (III) oleate. Monodispersity of the nanoparticles ensures their uniform physical and chemical properties. By simple variation of the reaction parameters, such as the temperature and concentration of the stabilizer, the particle size was tuned from 6 to $20 \mathrm{~nm}$. To facilitate particle dispersibility in aqueous media, $\mathrm{Fe}_{3} \mathrm{O}_{4}$ was coated by silica via reverse microemulsion technique. Some $\mathrm{Fe}_{3} \mathrm{O}_{4} \& \mathrm{SiO}_{2}$ particles were also functionalized with aminosilica to allow facile conjugation of PEG-NHS through amide bond formation. $\mathrm{Fe}_{3} \mathrm{O}_{4} \& \mathrm{SiO}_{2}$ nanoparticles had a core-shell structure with a homogeneous silica layer on the surface. The thickness of the silica shell was controlled by selection of the reaction parameters, such as the TMOS/ $\mathrm{Fe}_{3} \mathrm{O}_{4}$ ratio and volume of TMOS added. $\mathrm{Fe}_{3} \mathrm{O}_{4} \& \mathrm{SiO}_{2}$-PEG nanoparticles exhibited good colloidal stability in aqueous media, as confirmed by DLS and $\zeta$-potential measurements.

The uptake of $\mathrm{Fe}_{3} \mathrm{O}_{4} \& \mathrm{SiO}_{2}$-PEG nanoparticles by mNSCs was inferior to that of $\mathrm{Fe}_{3} \mathrm{O}_{4} \& \mathrm{SiO}_{2}$, in agreement with reports that PEG can protect the particles from the immune cell system. A biocompatibility evaluation showed that $\mathrm{Fe}_{3} \mathrm{O}_{4} \& \mathrm{SiO}_{2}$-PEG and $\mathrm{Fe}_{3} \mathrm{O}_{4} \& \mathrm{SiO}_{2}$ nanoparticles did not induce cytotoxic effects, although slight disturbances in cell function leading to ROS production, mitochondrial depolarization, and activation of antioxidative defense mechanisms may occur either upon internalization or even contact with the nanoparticles. Both types of nanoparticles at concentrations of $40 \mathrm{mg} \mathrm{L}^{-1}$ provided sufficient contrast for MRI, indicating their possible applications in cell labeling or as circulating contrast particles.

\section{Acknowledgements}

This project was supported by the Czech Science Foundation (No. 17-04918S) and EU FP7 grant GlowBrain (REGPOT-2012CT2012-316120). This article was based upon work from COST Action (CM1403), supported by COST (European Cooperation in
Science and Technology). The MR imaging was done at GlowLab Multimodal Imaging Facility, University of Zagreb School of Medicine, Croatia. We are grateful to Lada Brkić Ahmed, Željka Punčec, Ivan Alić, and Hrvoje Mlinarić for their valuable help during cell and MRI experiments. The authors also acknowledge support from the RECOOP HST Association and the participating Cedars-Sinai Medical Center and the Charles University in Prague, Department of Physical and Macromolecular Chemistry, for the opportunity of Uliana Kostiv's and Vitalii Patsula's doctoral studies. Electron microscopy at the Institute of Macromolecular Chemistry was supported through project POLYMAT LO1507 (Ministry of Education, Youth and Sports of the CR, program NPU I).

\section{Notes and references}

1 G. Schmid, Nanoparticles: from theory to application, Wiley, 2004.

2 E. C. Wang and A. Z. Wang, Integr. Biol., 2014, 6, 9-26.

3 T. H. Shin, Y. Choi, S. Kim and J. Cheon, Chem. Soc. Rev., 2015, 44, 4501-4516.

4 G. Unsoy, R. Khodadust, S. Yalcin, P. Mutlu and U. Gunduz, Eur. J. Pharm. Sci., 2014, 62, 243-250.

5 J. Dobson, Gene Ther., 2006, 13, 283-287.

6 O. Veiseh, J. W. Gunn and M. Zhang, Adv. Drug Delivery Rev., 2010, 62, 284-304.

7 D. Serantes, K. Simeonidis, M. Angelakeris, O. ChubykaloFesenko, M. Marciello, M. P. Morales, D. Baldomir and C. Martinez-Boubeta, J. Phys. Chem. C, 2004, 118, 5927-5934.

8 N. Ohnishi, H. Furukawa, H. Hideyuki, J. M. Wang, C. An, E. Fukusaki, K. Kataoka, K. Ueno and A. Kondo, Nanobiotechnology, 2006, 2, 43-49.

9 D. Horák, M. Babič, P. Jendelová, V. Herynek, M. Trchová, Z. Pientka, E. Pollert, M. Hájek and E. Syková, Bioconjugate Chem., 2007, 18, 635-644.

10 R. Strobel and S. Pratsinis, Direct synthesis of maghemite, magnetite and wüstite nanoparticles by flame spray pyrolysis, Adv. Powder Technol., 2009, 20, 190-194.

11 M. Viswanathiah, K. Tareen and V. Krishnamurthy, J. Cryst. Growth, 1980, 49, 189-192.

12 T. Sugimoto and K. Sakata, J. Colloid Interface Sci., 1992, 152, 587-590.

13 R. Bardhan, S. Lal, A. Joshi and N. J. Halas, Acc. Chem. Res., 2011, 44, 936-946.

14 R. Weissleder, D. D. Stark, B. L. Engelstad, B. R. Bacon, C. C. Compton, D. L. White, P. Jacobs and J. Lewis, AJR, Am. J. Roentgenol., 1989, 152, 167-173.

15 C. Tassa, S. Y. Shaw and R. Weissleder, Acc. Chem. Res., 2011, 44, 842-852.

16 W. Y. Rho, H. M. Kim, S. Kyeong, Y. L. Kang, D. H. Kim, H. Kang, C. Jeong, D. E. Kim, Y. S. Lee and B. H. Jun, J. Ind. Eng. Chem., 2014, 20, 2646-2649.

17 A. Guerrero-Martínez, J. Pérez-Juste and L. M. Liz-Marzán, Adv. Mater., 2010, 22, 1182-1195.

18 X. He, H. Nie, K. Wang, W. Tan, X. Wu and P. Zhang, Anal. Chem., 2008, 80, 9597-9603.

19 J. P. Almeida, A. L. Chen, A. Foster and R. Drezek, Nanomedicine, 2011, 6, 815-835. 
20 L. Wang, Z. Yang, J. Gao, K. Xu, H. Gu, B. Zhang, X. Zhang and B. A. Xu, J. Am. Chem. Soc., 2006, 128, 13358-13359.

21 L. X. Chen, T. Liu, M. C. Thurnauer, R. Csencsits and T. Rajh, J. Phys. Chem. B, 2002, 106, 8539-8546.

22 N. Nitin, L. LaConte, O. Zurkiya, X. Hu and G. Bao, J. Biol. Inorg Chem., 2004, 9, 706-712.

23 R. J. Wydra, P. G. Rychahou, B. M. Evers, K. W. Anderson, T. D. Dziubla and J. Z. Hilt, Acta Biomater., 2015, 25, 284-290.

24 C. I. Covaliu, D. Berger, C. Matei, L. Diamandescu, E. Vasile, C. Cristea, V. Ionita and H. Iovu, J. Nanopart. Res., 2011, 13, 6169-6180.

25 J. V. Jokerst, T. Lobovkina, R. N. Zare and S. S. Gambhir, Nanomedicine, 2011, 6, 715-728.

26 V. Patsula, E. Petrovský, J. Kovářová, R. Konefal and D. Horák, Colloid Polym. Sci., 2014, 292, 2097-2110.

27 I. M. Pongrac, M. Dobrivojević, L. Brkić Ahmed, M. Babič, M. Šlouf, D. Horák and S. Gajović, Beilstein J. Nanotechnol., 2016, 7, 926-936.

28 U. Kostiv, O. Janoušková, M. Šlouf, N. Kotov, H. Engstová, K. Smolková, P. Ježek and D. Horák, Nanoscale, 2015, 7, 18096-18104.

29 H. L. Ding, Y. X. Zhang, S. Wang, J. M. Xu, S. C. Xu and G. H. Li, Chem. Mater., 2012, 24, 4572-4580.

30 J. L. Lábár, Ultramicroscopy, 2005, 103, 237-249.

31 W. Kraus and G. Nolze, J. Appl. Crystallogr., 1996, 29, 301303.

32 S. Gražulis, A. Daškevič, A. Merkys, D. Chateigner, L. Lutterotti, M. Quirós, N. R. Serebryanaya, P. Moeck, R. T. Downs and A. Le Bail, Nucleic Acids Res., 2012, 40, D420-D427.

33 R. M. Zucker and K. M. Daniel, Methods Mol. Biol., 2012, 906, 497-509.

34 W. Overton, Cytometry, 1988, 9, 619-626.

35 I. Vinković Vrček, I. Pavičić, T. Crnković, D. Jurašin, M. Babič, D. Horák, M. Lovrić, L. Ferhatović, M. Ćurlin and S. Gajović, RSC Adv., 2015, 5, 70787-70807.

36 M. Birringer, D. Lington, S. Vertuani, S. Manfredini, D. Schartau, M. Glei and M. Ristow, Free Radical Biol. Med., 2010, 49, 1315-1322.

37 D. Stevenson, D. Wokosin, J. Girkin and M. H. Grant, Toxicol. In Vitro, 2002, 16, 609-619.
38 I. M. Pongrac, I. Pavičić, M. Milić, L. Brkić Ahmed, M. Babič, D. Horák, I. Vinković Vrček and S. Gajović, Int. J. Nanomed., 2016, 11, 1701-1715.

39 P. R. Hof, W. G. Young, F. E. Bloom, P. V. Belichenko and M. R. Celio, Comparative Cytoarchitectonic Atlas of the C57BL/6 and 129/Sv Mouse Brains, Elsevier, 2000.

40 V. Patsula, L. Kosinová, M. Lovrić, L. Ferhatovic Hamzić, M. Rabyk, R. Konefal, A. Paruzel, M. Šlouf, V. Herynek, S. Gajović and D. Horák, ACS Appl. Mater. Interfaces, 2016, 8, 7238-7247.

41 K. W. Andrews, D. J. Dyson and S. R. Keown, Interpretation of Electron Diffraction Patterns, Plenum Press, 1967.

42 V. Patsula, M. Moskvin, S. Dutz and D. Horák, J. Phys. Chem. Solids, 2016, 88, 24-30.

43 C. L. Chang and H. S. Fogler, Langmuir, 1997, 13, 3295-3307.

44 U. Kostiv, I. Kotelnikov, V. Proks, M. Šlouf, J. Kučka, H. Engstová, P. Ježek and D. Horák, ACS Appl. Mater. Interfaces, 2016, 8, 20422-20431.

45 J. W. Bulte, I. D. Duncan and J. A. Frank, J. Cereb. Blood Flow Metab., 2002, 22, 899-907.

46 M. Modo, D. Cash, K. Mellodew, S. C. Williams, S. E. Fraser, T. J. Meade, J. Price and H. Hodges, NeuroImage, 2002, 17, 803-811.

47 A. S. Arbab, L. B. Wilson, P. Ashari, E. K. Jordan, B. K. Lewis and J. A. Frank, NMR Biomed., 2005, 18, 383-389.

48 X. Jing, L. Yang, X. Duan, B. Xie, W. Chen, Z. Li and H. Tan, Jt., Bone, Spine, 2008, 75, 432-438.

49 M. C. Hohnholt, M. Geppert and R. Dringen, Acta Biomater., 2011, 7, 3946-3954.

50 H. Sies, Free Radical Biol. Med., 1999, 27, 916-921.

51 G. G. Xiao, M. Wang, N. Li, J. A. Loo and A. E. Nel, J. Biol. Chem., 2003, 278, 50781-50790.

52 M. Könczöl, S. Ebeling, E. Goldenberg, F. Treude, R. Gminski, R. Gieré, B. Grobéty, B. Rothen-Rutishauser, I. Merfort and V. Mersch-Sundermann, Chem. Res. Toxicol., 2011, 24, 1460-1475.

53 L. Galluzzi, N. Larochette, N. Zamzami and G. Kroemer, Oncogene, 2006, 25, 4812-4830.

54 D. N. Guilfoyle, V. V. Dyakin, J. O'Shea, G. S. Pell and J. A. Helpern, Magn. Reson. Med., 2003, 49, 576-580.

55 D. W. McRobbie, E. A. Moore, M. J. Graves and M. R. Prince, MRI From Picture To Proton, Cambridge University Press, 2007. 